\title{
Lamb production responses to grass grazing in a companion crop system with corn silage and oversowing of yellow oat in a tropical region
}

\author{
Cristiano M. Pariz ${ }^{\text {a,* }}$, Ciniro Costa ${ }^{\text {a }}$, Carlos A.C. Crusciol ${ }^{\text {b }}$, André M. Castilhos ${ }^{\text {a }}$, Paulo R.L. Meirelles ${ }^{\text {a }}$, \\ Roberto O. Roça ${ }^{\mathrm{c}}$, Rafael S.B. Pinheiro ${ }^{\mathrm{d}}$, Frank A. Kuwahara ${ }^{\mathrm{e}}$, Jorge M. Martello ${ }^{\mathrm{b}}$, Francielli A. Cavasano ${ }^{\mathrm{a}}$, \\ Júnior I. Yasuoka ${ }^{\mathrm{f}}$, Jaqueline R.W. Sarto ${ }^{\mathrm{a}}$, Verônica F.P. Melo ${ }^{\mathrm{a}}$, Alan J. Franzluebbers ${ }^{\mathrm{g}}$ \\ a São Paulo State University (UNESP), College of Veterinary Medicine and Animal Science, Department of Animal Nutrition and Breeding, Botucatu, State of São Paulo, Brazil \\ ${ }^{\mathrm{b}}$ UNESP, College of Agricultural Science, Department of Crop Science, Botucatu, State of São Paulo, Brazil \\ ' UNESP, College of Agricultural Science, Department of Economy, Sociology and Technology, Botucatu, State of São Paulo, Brazil \\ d UNESP, College of Engineering, Department of Biology and Animal Science, Ilha Solteira, State of São Paulo, Brazil \\ e University of the West of São Paulo (UNOESTE), Presidente Prudente, State of São Paulo, Brazil \\ ${ }^{\mathrm{f}}$ University of São Paulo (USP), College of Agriculture, Piracicaba, State of São Paulo, Brazil \\ ${ }^{g}$ USDA-ARS, 3218 Williams Hall, Campus Box 7619, North Carolina State Univ., Raleigh, NC 27695-7619, USA
}

\section{A R T I C L E I N F O}

\section{Article history:}

Received 23 August 2016

Received in revised form 9 November 2016

Accepted 10 November 2016

Available online 16 November 2016

\section{Keywords:}

Animal carcass

Avena byzantina

Integrated crop-livestock system

Live weight gain

Urochloa brizantha

Total operating cost

\begin{abstract}
A B S T R A C T
Integrated crop-livestock systems in regions with dry winters could be a viable option to increase food production during periods of irregular rain and reduced pasture availability. A corn (Zea mays L.) silage production system with cover crops of (a) the weedy growth of signal grass [Urochloa decumbens (Stapf) R. Webster "Basilisk"] and (b) palisade grass [Urochloa brizantha (Hochst. ex A. Rich.) R. Webster 'Marandu' and 'Piatã'], both with a 0.20 - and 0.45 -m silage cutting height, was employed in the summer and autumn. Yellow oat (Avena byzantina cv. São Carlos) was oversown in these systems in the winter and spring. The pasture production, the daily ration intake, the performance and carcass characteristics of lambs (Ovis aries) grazing these pastures in a semi-feedlot system (supplemented with silage and concentrate), and the revenue were investigated. The experiment was repeated in the same location for two growing seasons (2010-2011 and 2011-2012) on a Typic Haplorthox in Botucatu, São Paulo, Brazil. Analyzing the system as a whole, intercropping corn silage with palisade grass cv. Marandu (followed by palisade grass cv. Piatã) with a cutting height of $0.45 \mathrm{~m}$ combined with yellow oat oversowing was the most robust option for enhancing productivity. The pasture formation for lamb finishing in a semi-feedlot system, the reduction of silage and concentrate intake, and greater live weight and carcass gains per hectare were key attributes for improving the economic viability of this integrated crop-livestock system. Thus, these crop systems were a viable option for the diversification of agricultural activities in tropical regions.
\end{abstract}

(C) 2016 Elsevier Ltd. All rights reserved.

\section{Introduction}

According to the FAO (2016), more than one billion individuals (approximately $15 \%$ of the human population) worldwide are hungry and are living in poverty. The majority of this population, as well as others living in near poverty, reside in rural areas and depend on agriculture for their livelihood; the agriculture in these areas is primarily based on small-scale, integrated crop-livestock systems (ICLS). Producers using mixed farming systems may value crop residues as much as they value grains, given that residues are a vital livestock feed in the dry season. The improvement of mixed crop and livestock production is crucial to elevate the social and economic conditions for small-scale producers and to mitigate human suffering (Herrero et al., 2010).

\footnotetext{
* Corresponding author.

E-mail address: cmpzoo@gmail.com (C.M. Pariz).
}

Currently, the combination of ICLS with no tillage systems (NTS) may be one of the best alternatives for farmers to gain income while simultaneously achieving sustainability in the tropical region, such as the Brazilian "Cerrado" and the African "Savanna". Integrated crop-livestock systems are considered as the "new green revolution in the tropics" (Mateus et al., 2012) due to their productive economic and environmental benefits and their potential contribution to increased global food production for the future (Franzluebbers and Stuedemann, 2014; Wirsenius et al., 2010).

In Brazil, degraded pastures (i.e., low forage yield per area) cover approximately 80 million ha (Mha) (Crusciol et al., 2014). Pasture recovery can be performed by intercropping tropical forage and cash crops using a combination of ICLS and an NTS. Thus, the introduction of forage plants intercropped with grain crops could be a key strategy to enhance the early establishment and successful production of a dry winter season (low and irregular rainfall) forage for grazing (Pariz et al., 2010, 
2011a, 2011b, 2011c, 2016; Crusciol et al., 2011, 2012, 2013, 2014, 2016; Mateus et al., 2011, 2016; Borghi et al., 2012, 2013a, 2013b; Costa et al., 2012, 2016).

A silage crop that is cut low to the ground can negatively affect the survival and production of tropical forages intercropped with cash crops (Pariz et al., 2016). Low cutting height could remove valuable tillers, thus compromising pasture development. Therefore, developing sustainable no-tillage silage production systems is required, especially when combined with promising ICLS production strategies to improve overall agricultural functionality.

Another promising option in ICLS is the rotation or succession of summer crops, such as soybean (Glycine max), corn, common bean (Phaseolus vulgaris) or rice (Oryza sativa), with winter annual grazing grasses, such as oat (Avena) and ryegrass (Lolium multiflorum), either mixed or separately (Moraes et al., 2014a). In southern Brazil, oversowing soybean and corn with oat is a viable alternative to increase forage and meat production in winter and spring (Lopes et al., 2008).

Brazil has 17.4 million sheep (IBGE, 2010), and the Brazilian sheep industry has great potential for expansion, given the vast territory with a high potential for forage production (Carvalho et al., 2010). However, in Brazil, beef cattle and lamb production is generally based on the grazing of degraded pastures with low stocking rate, low live-weight gain, and low carcass yield per area (Pariz et al., 2011d). There is great opportunity to for lamb finishing in ICLS as a viable strategy for increasing meat production (Barth Neto et al., 2014). A semi-feedlot system (a semi-intensive system with lambs grazing the pasture and supplementing with silage and/or concentrate) has the potential to increase meat production (Barros et al., 2009). Thus, lamb finishing in semi-feedlots within ICLS may be a viable strategy for increasing the meat production of both beef and sheep.

In recent studies on ICLS, only approximately $5 \%$ of studies have directly measured animal responses (Moraes et al., 2014b), and only $2.4 \%$ of studies evaluated animal supplemental feeding in ICLS. This topic could be relevant due to challenges from the genetic potential of animals that are offered the usual high-quality diet allowed by ICLS. Additionally, the quality of animal products produced in ICLS has received limited attention from researchers, although this quality is a relevant aspect in the commercialization of these products and in the purchasing decisions of consumers.

The hypotheses for this study were that a) a higher cutting height of corn silage intercropped with cultivars of palisade grass in the summer/ autumn and associated with yellow oat oversowing in the winter/spring provides increased pasture production in tropical regions characterized by dry winters and b) a greater pasture production provides a better performance and carcass characteristics of lambs grazing in a semifeedlot system, decreased daily ration intake, and increased revenue compared with corn only (with weedy regrowth of volunteer signal grass). Thus, the pasture production of yellow oat overseeded onto corn silage, the lamb daily ration intake, the lamb performance and carcass characteristics in a semi-feedlot system (supplemented with silage of the same treatment and concentrate), and the revenue were evaluated in ICLS during two growing seasons in the Brazilian "Cerrado".

\section{Materials and methods}

This study was conducted in accordance with the Ethics Committee on Animal Use (CEUA) of São Paulo State University (UNESP), College of Veterinary Medicine and Animal Science, Botucatu, São Paulo, Brazil, under protocol number 166/2010-CEUA.

\subsection{Site description}

The experiment was conducted in Botucatu, São Paulo, Brazil ( $48^{\circ}$ $25^{\prime} 28^{\prime \prime} \mathrm{W}, 22^{\circ} 51^{\prime} 01^{\prime \prime} \mathrm{S}$, and $777 \mathrm{~m}$ above sea level), during two consecutive growing seasons: 2010-2011 and 2011-2012. The soil was a clayey, kaolinitic, thermic Typic Haplorthox (FAO, 2006) with 630, 90 and $280 \mathrm{~g} \mathrm{~kg}^{-1}$ of clay, silt and sand, respectively. For four years, until October 2010, the field was fallow, with predominantly signal grass and annual broadleaf weeds.

The climate was Cwa, characterized by tropical conditions with dry winters and hot, rainy summers, according to the Köppen climate classification system (Alvares et al., 2013). The long-term (1956-2013) mean annual maximum and minimum temperatures were $26.1{ }^{\circ} \mathrm{C}$ and $15.3^{\circ} \mathrm{C}$, respectively, with a mean annual precipitation of $1358 \mathrm{~mm}$ (Unicamp, 2012). The precipitation and temperature were measured from 2010 to 2012 (Table 1).

Before initiating the experiment, soil compaction was evaluated at 20 points per hectare as soil penetration resistance using an impact penetrometer (Model Stolf Reduced; Stolf et al., 2014). The ideal soil moisture conditions for the determination of soil penetration resistance range between full field capacity and $1 / 3$ field capacity, as defined by Kiehl (1979). In practical terms, these conditions occur when the soil volumetric moisture content is $0.22-0.33 \mathrm{~m}^{3} \mathrm{~m}^{-3}$. The mean soil penetration resistance was $0.63,0.92,1.51$, and $1.93 \mathrm{MPa}$ at the depths of 0 $0.10,0.10-0.20,0.20-0.30$, and $0.30-0.40 \mathrm{~m}$, respectively. These values are considered low ( $<1 \mathrm{Mpa}$ ) to moderate (1-2 Mpa) (Arshad et al., 1996); thus, the study with no soil disturbance was implemented. The chemical characteristics of soil at depths of $0-0.20$ and $0.20-0.40 \mathrm{~m}$ were determined (Table 2). Soil pH was measured in a $0.01 \mathrm{~mol} \mathrm{~L}^{-1}$ $\mathrm{CaCl}_{2}$ suspension (1:2.5 soil/solution). Soil organic matter was determined with a colorimetric method using a sodium dichromate solution. Total acidity at $\mathrm{pH} 7.0(\mathrm{H}, \mathrm{Al})$ was extracted with $0.5 \mathrm{~mol} \mathrm{~L}^{-1}$ calcium acetate and determined through titration with a $0.025 \mathrm{~mol} \mathrm{~L}^{-1} \mathrm{NaOH}$ solution. Exchangeable Al was extracted with neutral $1 \mathrm{~mol} \mathrm{~L}^{-1} \mathrm{KCl}$ at

Table 1

Rainfall and maximum and minimum temperatures at Botucatu, São Paulo, Brazil, during the study period and the long-term averages.

\begin{tabular}{|c|c|c|c|c|c|c|c|c|c|c|c|c|}
\hline \multirow[t]{2}{*}{ Climate characteristics } & \multicolumn{12}{|c|}{ Month } \\
\hline & Dec. & Jan. & Feb. & Mar. & Apr. & May & June & July & Aug. & Sept. & Oct. & Nov. \\
\hline \multicolumn{13}{|l|}{$2010-2011$} \\
\hline Monthly rain, mm & 243 & 712 & 188 & 164 & 127 & 17 & 50 & 7 & 25 & 0 & 360 & 103 \\
\hline Mean max. temp., ${ }^{\circ} \mathrm{C}$ & 28.6 & 29.6 & 29.8 & 25.8 & 26.8 & 23.5 & 21.9 & 24.6 & 26.4 & 28.2 & 26.7 & 27.7 \\
\hline Mean min. temp., ${ }^{\circ} \mathrm{C}$ & 18.3 & 19.6 & 19.6 & 18.3 & 15.9 & 12.9 & 10.9 & 12.2 & 14.3 & 13.4 & 16.7 & 15.7 \\
\hline \multicolumn{13}{|l|}{ 2011-2012 } \\
\hline Monthly rain, mm & 143 & 357 & 167 & 59 & 250 & 78 & 228 & 23 & 0 & 51 & 159 & 104 \\
\hline Mean max. temp., ${ }^{\circ} \mathrm{C}$ & 30.5 & 29.3 & 32.1 & 30.8 & 28.5 & 23.9 & 21.5 & 23.5 & 25.8 & 28.1 & 29.7 & 27.9 \\
\hline Mean min. temp., ${ }^{\circ} \mathrm{C}$ & 17.8 & 17.5 & 20.1 & 18.4 & 17.7 & 13.9 & 14.2 & 12.6 & 14.4 & 15.6 & 18.1 & 19.2 \\
\hline \multicolumn{13}{|l|}{ Long-term (50 yr) avg. } \\
\hline Monthly rain, mm & 185 & 224 & 203 & 141 & 67 & 76 & 56 & 38 & 39 & 71 & 127 & 133 \\
\hline Mean max. temp., ${ }^{\circ} \mathrm{C}$ & 27.2 & 28.1 & 28.0 & 28.0 & 27.0 & 24.0 & 23.0 & 23.0 & 25.0 & 26.2 & 26.7 & 27.2 \\
\hline Mean min. temp., ${ }^{\circ} \mathrm{C}$ & 16.4 & 17.1 & 17.4 & 19.0 & 17.0 & 15.0 & 13.0 & 13.0 & 14.0 & 12.4 & 14.2 & 15.1 \\
\hline Photoperiod, h day ${ }^{-1}$ & 13.3 & 13.2 & 12.7 & 12.1 & 11.5 & 10.9 & 10.7 & 10.8 & 11.2 & 11.9 & 12.5 & 13.1 \\
\hline
\end{tabular}


Table 2

Soil chemical characteristics at two depths in the experimental area before the initiation of the experiment.

\begin{tabular}{|c|c|c|c|c|c|c|c|c|c|}
\hline Depth & $\begin{array}{l}\mathrm{pH} \\
\mathrm{CaCl}_{2}\end{array}$ & $\begin{array}{l}\mathrm{SOM}^{\mathrm{a}} \\
\mathrm{g} \mathrm{dm}^{-3}\end{array}$ & $\begin{array}{l}\mathrm{P}(\text { resin }) \\
\mathrm{mg} \mathrm{dm}^{-3}\end{array}$ & $\begin{array}{l}\mathrm{H}+\mathrm{Al} \\
\mathrm{mmol}_{\mathrm{c}} \cdot \mathrm{dm}^{-3}\end{array}$ & $\mathrm{~K}_{\mathrm{ex}}$ & $\mathrm{Ca}_{\mathrm{ex}}$ & $\mathrm{Mg}_{\mathrm{ex}}$ & $\mathrm{CEC}^{\mathrm{b}}$ & $\begin{array}{l}\mathrm{BS}^{\mathrm{C}} \\
\%\end{array}$ \\
\hline $0-0.20 \mathrm{~m}$ & 4.7 & 46.5 & 8.2 & 45.7 & 0.8 & 21.4 & 11.2 & 79.1 & 42.2 \\
\hline $0.20-0.40 \mathrm{~m}$ & 4.3 & 36.3 & 6.8 & 64.1 & 0.6 & 12.1 & 6.5 & 83.3 & 23.0 \\
\hline
\end{tabular}

a Soil organic matter.

b Cation exchange capacity.

c Base saturation.

a 1:10 soil/solution ratio and determined by titration with a $0.025 \mathrm{~mol} \mathrm{~L}^{-1} \mathrm{NaOH}$ solution. Available P and exchangeable $\mathrm{Ca}, \mathrm{Mg}$, and $\mathrm{K}$ were extracted using an ion exchange resin and determined via atomic absorption spectrophotometry. The cation exchange capacity (CEC) was calculated from the sum of the concentrations of $\mathrm{H}+, \mathrm{Al}, \mathrm{K}$, $\mathrm{Ca}$, and $\mathrm{Mg}$ cations. Base saturation (BS) was calculated by dividing the sum of $\mathrm{K}, \mathrm{Mg}$, and $\mathrm{Ca}$ (the bases) by the CEC and multiplying the result by $100 \%$ (van Raij et al., 2001).

\subsection{Experimental design}

The experiment was a randomized complete block design consisting of six crop systems and four replications. The crop systems consisted of (A) three intercropping systems for corn silage - without intercropping with only volunteer signal grass and with introduced forage (palisade grass cv. Marandu or cv. Piatã) and (B) two cutting heights for silage -0.20 and $0.45 \mathrm{~m}$ above the soil surface. The experiment was repeated in the same location for two growing seasons (2010-2011 and 20112012). Each plot consisted of twenty 25 -m-long rows spaced $0.45 \mathrm{~m}$ apart, thus providing a total area of $450 \mathrm{~m}^{2}$.

Crop systems were evaluated with a subplot treatment in the absence or in the presence of yellow oat cv. São Carlos. After the corn harvest for silage was complete, plots were divided into two subplots of the same size. The experiment was repeated in the same location for two growing seasons (2010-2011 and 2011-2012).

\subsection{Tillage and crop management}

On 22 October 2010, residual weeds (signal grass and annual broadleaf) were sprayed with glyphosate [isopropylamine salt of $\mathrm{N}$ (phosphonomethyl)glycine; $1.08 \mathrm{~kg}$ acid-equivalent ha ${ }^{-1}$ and 2.4-D amine (2.4-Dichlorophenoxyacetic acid); $0.67 \mathrm{~kg}$ active ingredient $\mathrm{ha}^{-1}$ ], using a spray volume of $200 \mathrm{~L} \mathrm{ha}^{-1}$. On 26 October 2010, plant material was cut using a plant residue crusher, leaving $8.5 \mathrm{Mg} \mathrm{ha}^{-1}$ of straw on the soil surface. On 3 November $2010,2.5 \mathrm{Mg} \mathrm{ha}^{-1}$ of dolomitic lime $\left(\mathrm{CaCO}_{3} \cdot \mathrm{MgCO}_{3}\right)$ with $28 \% \mathrm{CaO}$ and $20 \% \mathrm{MgO}$ was dispersed onto the soil. On 4 November $2010,1.5 \mathrm{Mg} \mathrm{ha}^{-1}$ of agricultural gypsum $\left(\mathrm{CaSO}_{4} \cdot 2 \mathrm{H}_{2} \mathrm{O}\right)$ with $17 \% \mathrm{Ca}$ and $14 \% \mathrm{~S}$ was dispersed, following the recommendation of Cantarella et al. (1997). On 7 December 2010, any weed regrowth was sprayed with glyphosate (1.44 kg acid-equivalent $\mathrm{ha}^{-1}$ ) and 2.4-D amine ( $0.67 \mathrm{~kg}$ active ingredient ha $\left.{ }^{-1}\right)$, using a spray volume of $200 \mathrm{~L} \mathrm{ha}^{-1}$, leaving $1.5 \mathrm{Mg} \mathrm{ha}^{-1}$ of additional straw on the soil surface.

Corn hybrid 2B587 HX (with early relative maturity) was sown in all crop systems on 20 December 2010 and 21 December 2011 at a 4-cm depth, with a row spacing of $0.45 \mathrm{~m}$ and a density of 80,000 seeds $\mathrm{ha}^{-1}$, using no-till seeding. For all crop systems and in both growing seasons, basic fertilization in the sowing furrows consisted of $36 \mathrm{~kg} \mathrm{ha}^{-1}$ of $\mathrm{N}$ as urea, $126 \mathrm{~kg} \mathrm{ha}^{-1}$ of $\mathrm{P}_{2} \mathrm{O}_{5}$ as triple superphosphate, and $72 \mathrm{~kg} \mathrm{ha}^{-1}$ of $\mathrm{K}_{2} \mathrm{O}$ as potassium chloride, following the recommendation of Cantarella et al. (1997). As an intercrop with corn, palisade grass was simultaneously sown at $10.8 \mathrm{~kg} \mathrm{ha}^{-1}$ (pure live seed $=60 \%$ ). Forage seeds were mixed with basic fertilizer (Mateus et al., 2007) and sown at depths of $8 \mathrm{~cm}$ below the soil surface, as described by Crusciol et al. (2012).
Corn seedling emergence occurred at 6 and 16 days after sowing ( 26 December 2010 and 6 January 2012, respectively). Differences were due to the absence of rain after sowing in the second growing season (Table 1). Grass seedlings emerged at 11 and 18 days after sowing (31 December 2010 and 8 January 2012, respectively). On 7 January 2011 and 25 January 2012, nicosulfuron \{[2-(4,6-dimethoxypyrimidin-2ylcarbamoyl)sulfamoyl]- $N, N$-dimethylnicotinamide]; 8 g active ingredient $\mathrm{ha}^{-1}$ \} and atrazine (6-chloro- $\mathrm{N}^{2}$-ethyll- $\mathrm{N}^{4}$-isopropyl-1,3,5triazine-2,4-diamine; $1.25 \mathrm{~kg}$ active ingredient $\mathrm{ha}^{-1}$ ) were applied using a $200 \mathrm{~L} \mathrm{ha}^{-1}$ spray volume to reduce initial grass seedling growth and to control the emergence of annual broadleaf weeds.

When the corn showed five expanded leaves (V5 stage), mineral fertilizer was dispersed with no incorporation at $90 \mathrm{~kg} \mathrm{ha}^{-1}$ of $\mathrm{N}$ as urea and $67 \mathrm{~kg} \mathrm{ha}^{-1}$ of $\mathrm{K}_{2} \mathrm{O}$ as potassium chloride in the first growing season and $150 \mathrm{~kg} \mathrm{ha}^{-1}$ of $\mathrm{N}$ as urea and $90 \mathrm{~kg} \mathrm{ha}^{-1}$ of $\mathrm{K}_{2} \mathrm{O}$ as potassium chloride in the second growing season, following the recommendation of Cantarella et al. (1997). Greater rates of application of $\mathrm{N}$ and $\mathrm{K}_{2} \mathrm{O}$ in the second growing season were in response to nutritional deficiencies found in corn leaves in the first growing season.

The average corn growing season length from emergence to grain with 33-34\% moisture was 107 and 102 days in the first and second growing seasons, respectively. Whole corn plants were harvested in each plot with a mechanical silage forage harvester at the appropriate cutting height for each treatment $(0.20$ and $0.45 \mathrm{~m}$ above the soil surface). Crops were chopped into particles with an average size of 1.5 and $1.0 \mathrm{~cm}$ in the first and second growing seasons, respectively. A one-line platform ( $0.90 \mathrm{~m}$ spacing between rows) in the first growing season and a two-line platform with reduced spacing $(0.45$ to $0.55 \mathrm{~m}$ between rows) in the second growing season to harvest silage crops were used. In the second growing season, knives of the mechanical forage harvester were used to shred the corn silage grain. In both growing seasons, silage was stored in silo-type "bags" that were $1.50 \mathrm{~m}$ in diameter and packed at a fresh matter density of $600 \mathrm{~kg} \mathrm{~m}^{-3}$.

On 19 May 2011 and 21 May 2012, yellow oat was oversown at a depth of $3 \mathrm{~cm}$, with a $0.17-\mathrm{m}$ row spacing and 70 and $62 \mathrm{~kg} \mathrm{ha}^{-1}$ pure live seed density in the first and second growing seasons, respectively, using no-till seeding. Yellow oat seedlings emerged at 20 and 9 days after sowing (8 June 2011 and 30 May 2012, respectively). Differences in emergence were due to the absence of rain after oversowing in the first crop year (Table 1$)$.

On 9 June 2011 and 1 June 2012, grasses and yellow oat were fertilized with $60 \mathrm{~kg} \mathrm{ha}^{-1}$ of $\mathrm{N}$ as ammonium sulfate. In the early years of notill systems, plants have high $\mathrm{N}$ requirement (Anghinoni, 2007), and fertilization increases grass yields after corn harvest (Pariz et al., 2011a, 2011b; Borghi et al., 2014).

On 14 December 2011 and 4 December 2012, pastures composed of the remaining forage grasses and weeds were sprayed with glyphosate (1.44 kg acid-equivalent ha ${ }^{-1}$ ), using a spray volume of $200 \mathrm{~L} \mathrm{ha}^{-1}$.

\subsection{Lamb grazing management}

In both growing seasons, 144 uncastrated male crossbred Santa Inês lambs (Ovis aries) with a mean age of three months were evaluated from August to December. Lambs were ear tagged and vaccinated (with the commercial product "Excell 10"). The animals were also dewormed with an application of levamisole hydrochloride and 
nitroxynil 34\% in the first and second growing seasons, respectively. Lambs were grouped based on live weight variation, and members of a group were randomly allocated to treatments. The experimental unit was the subplot, into which three groups of lambs were allocated.

The grazing method was continuous stocking with a fixed stocking rate of 133 lambs ha ${ }^{-1}$ in a semi-feedlot scheme. In both growing seasons, worms were monitored every $14-\mathrm{d}$ period using the FAMACHA ${ }^{\circledR}$ method as described by Molento (2009). Lambs were individually sampled, and infected lambs were dewormed with applications of nitroxynil $34 \%$.

Lamb dietary adjustment periods occurred from 15 to 22 September 2011 and from 21 August - 6 September 2012, corresponding to 99 and 83 days after yellow oat seedling emergence, respectively. On 22 September 2011 and 6 September 2012, lambs were weighed to initiate the experimental period.

Pasture paddocks were enclosed with electric fencing (six strips), and lambs had free access to water. In the second growing season, lambs also had access to a shade cloth. Throughout the day, lambs were on pasture, and at night, they entered a cote, where they were supplemented with additional corn silage of the same treatment and same concentrate for all treatments. Three lambs from each paddock were kept in the same pen $(1.73 \times 1.73 \mathrm{~m})$ in the covered holding yar and had free access to water.

The semi-feedlot experiment lasted 70 days in the first growing season (2010 - 2011), i.e., five 14-d periods. The roughage:concentrate ratio for all treatments was 60:40 in Periods 1 and 2 (22 September 19 October 2011), 50:50 in Periods 3 and 4 (20 October - 16 November 2011 ) and 40:60 in Period 5 (17-30 November 2011). The estimated dry matter intake was $3.27 \%$ of live weight, for an average daily live weight gain of $100.0 \mathrm{~g}$ (NRC, 2007) in all periods. In the second growing season (2011-2012), the experiment also lasted 70 days, but the roughage:concentrate ratio for all treatments was 60:40 in all periods (6 September - 14 November 2012). The estimated dry matter intake was $3.25 \%$ of live weight, for an average daily live weight gain of $132.0 \mathrm{~g}$ (NRC, 2007) in all periods due to the greater forage mass of pasture from leaves than that in the first growing season.

In all treatments, pasture accounted for approximately $15 \%$ of dry matter intake; the remainder was provided as corn silage (produced in the same area in the summer/autumn) and concentrate according to the daily need. At the end of each 14-d period, lambs were individually weighed using a mobile electronic scale to adjust the amount of feed to be supplied and to monitor live weight gain. Final weights were recorded on 1 December 2011 and 15 November 2012 (for the first and second growing seasons, respectively). Subsequently, lambs were transported to a commercial slaughterhouse.

The lamb's diet was computer formulated using the Small Ruminant Nutrition System (SRNS) program based on the Cornell Net Carbohydrate and Protein System (2000) for sheep. Table 3 shows the ingredients and nutritional composition of the diets during the experimental period. On a daily basis, $10 \%$ greater allowance was provided according to live weight considering the waste and pen behavior. Diet components were weighed and mixed daily, and ration leftovers per pen were weighed daily.

\subsection{Sampling and analyses}

\subsubsection{Forage mass of pasture}

Prior to each 14-d grazing period by lambs, the forage mass of the pasture was determined by cutting three representative $1.0-\mathrm{m}^{2}$ areas per plot to ground level using a mechanical rotary mower. Forage samples were dried using forced-air circulation at $65^{\circ} \mathrm{C}$ for $72 \mathrm{~h}$, weighed, and reported as $\mathrm{Mg} \mathrm{ha}^{-1}$. In subplots with yellow oat, this forage species was individually evaluated only in the first and second 14-d periods. Yellow oat flourished before the start of lamb grazing but without significant regrowth in subsequent 14 -d periods.
Table 3

Ingredients and nutritional composition of lamb diets during the experimental period.

\begin{tabular}{|c|c|c|c|c|}
\hline & \multicolumn{3}{|c|}{ First growing season } & \multirow{3}{*}{$\begin{array}{l}\text { Second growing season } \\
\text { Periods } \\
1 \text { to } 5\end{array}$} \\
\hline & \multicolumn{3}{|l|}{ Periods } & \\
\hline & 1 and 2 & 3 and 4 & 5 & \\
\hline \multicolumn{5}{|l|}{ Ingredients, \% of DM } \\
\hline Corn silage & 45.0 & 35.7 & 25.0 & 45.0 \\
\hline Ground corn - $6 \mathrm{~mm}$ sieve & 7.3 & 15.5 & 24.2 & 20.7 \\
\hline Soybean meal & 24.0 & 24.0 & 25.4 & 16.4 \\
\hline Ground rice grain $-3 \mathrm{~mm}$ sieve & 5.6 & 5.7 & 5.9 & 0.00 \\
\hline Vitamin mineral supplement $\mathrm{t}^{\mathrm{a}}$ & 3.1 & 3.9 & 4.0 & 2.3 \\
\hline Limestone & 0.0 & 0.00 & 0.00 & 0.6 \\
\hline Pasture & 15.0 & 15.2 & 15.5 & 15.0 \\
\hline \multicolumn{5}{|l|}{ Chemical composition $^{b}$, DM basis } \\
\hline $\mathrm{DM}, \%$ as fed basis & 53.9 & 59.1 & 65.0 & 57.8 \\
\hline $\mathrm{ME}^{\mathrm{c}}, \mathrm{Mcal} / \mathrm{kg}$ & 2.5 & 2.6 & 2.6 & 2.6 \\
\hline $\mathrm{NEm}^{\mathrm{c}}, \mathrm{Mcal} / \mathrm{kg}$ & 1.6 & 1.6 & 1.7 & 1.6 \\
\hline $\mathrm{NEg}^{\mathrm{c}}, \mathrm{Mcal} / \mathrm{kg}$ & 0.9 & 1.0 & 1.1 & 1.0 \\
\hline $\mathrm{CP}, \%$ & 16.7 & 16.8 & 17.6 & 13.8 \\
\hline $\mathrm{MP}^{\mathrm{c}}, \%$ & 11.5 & 11.5 & 11.9 & 10.9 \\
\hline NDF, \% & 39.5 & 35.6 & 31.3 & 39.0 \\
\hline peNDF $^{\mathrm{d}}, \%$ & 28.3 & 24.1 & 20.3 & 28.5 \\
\hline $\mathrm{NFC}^{\mathrm{d}}, \%$ & 33.9 & 36.9 & 40.3 & 37.8 \\
\hline $\mathrm{EE}^{\mathrm{d}}, \%$ & 3.1 & 3.2 & 3.4 & 3.1 \\
\hline Ca, $\%$ & 0.7 & 0.8 & 0.8 & 0.7 \\
\hline $\mathrm{P}, \%$ & 0.6 & 0.6 & 0.6 & 0.6 \\
\hline
\end{tabular}

a Levels of minimum guarantee per kg of product - Ca: $135 \mathrm{~g}$ and $150 \mathrm{~g}$ (maximum); $\mathrm{P}$ : 65 g; Na: 107 g; S: 12 g; Mg: 6000 mg; Co: 175 mg; Cu: 100 mg; I: 175 mg; Mn: 1440 mg; Se: $27 \mathrm{mg}$; Zn: $6000 \mathrm{mg}$; Fe: $1000 \mathrm{mg}$; and F: $650 \mathrm{mg}$ (maximum);

${ }^{\mathrm{b}} \mathrm{DM}=$ dry matter; $\mathrm{ME}=$ metabolizable energy; $\mathrm{NEm}=$ net energy for maintenance; $\mathrm{NEg}=$ net energy for gain; $\mathrm{CP}=$ crude protein; $\mathrm{MP}=$ metabolizable protein; $\mathrm{NDF}=$ neutral detergent fiber; peNDF = physically effective neutral detergent fiber; $\mathrm{NFC}=$ non-fibrous carbohydrate, and $\mathrm{EE}=$ ether extract;

c Values calculated using the Small Ruminant Nutrition System (SRNS) program;

${ }^{\mathrm{d}}$ peNDF = physically effective NDF was assumed to be the NDF content of the material retained on a 1.18-mm sieve, as a proportion of the total DM (Mertens, 1997), determined using the Penn State Particle Separator method (Heinrichs, 1996).

2.5.2. Daily ration intake, performance and carcass characteristics of lambs

The daily ration intake (corn silage and concentrate) was calculated as the difference between the ration supplied and that remaining. This value was converted to dry matter as a function of body weight. The average daily live weight gain (for the entire experimental period) was calculated as the difference between lamb live weight on slaughter day and live weight on the first day of stocking divided by the number of stocking days. The daily live weight gain per 14-d period was also calculated. Using these weights, the initial and final stocking rates of pastures were calculated.

Before the lambs were slaughtered, they were held without food and water for $16 \mathrm{~h}$ and then weighed and numbed according to the humane slaughter method described by the Ministry of Agriculture, Livestock and Supply (Brasil, 2000). Carcasses were identified with numbered labels on the gastrocnemius tendon, and after evisceration, they were weighed, washed with a jet of hyperchlorinated water spray and cooled in cold storage at $4{ }^{\circ} \mathrm{C}$ for $24 \mathrm{~h}$. The cold carcass weight was determined. The subcutaneous fat cover on the carcass was scored ( 1 to 5 , with intervals of 0.5 ) using the score averages assigned by three trained evaluators (Silva Sobrinho, 2001).

\subsubsection{Economic evaluation}

The total operating costs were estimated using technical coefficients (inputs and operations), extrapolated to 1 ha and adjusted to the prevailing market prices for commercial farms in the state of São Paulo, Brazil (Matsunaga et al., 1976). The average lamb cold carcass weight in $\mathrm{kg} \mathrm{ha}^{-1}$ of each treatment was used for revenue calculation. The Brazilian national average price for the past five years was used, and these values were converted to U.S. dollars (Agrolink, 2016). According to the methodology described by Santos et al. (2008), the contribution 
margin was calculated as the revenue from the sale of lamb carcasses minus the total operating costs.

\subsection{Statistical analyses}

All data were initially tested for normality using the Shapiro and Wilk (1965) test from the UNIVARIATE procedures (SAS Inst. Inc., Cary, NC, 2015). All data were distributed normally ( $\mathrm{W} \geq 0.90$ ). Data were analyzed using the PROC MIXED procedure in SAS and the Satterthwaite approximation to determine the denominator degrees of freedom for the test of fixed effects. Overall, the crop system was considered a fixed effect, and the block was a random effect. In the evaluation of grazed subplots, the model statement used for the analysis of forage mass and animal production characteristics contained the effects of crop systems, yellow oat oversowing and their resultant interaction. A repeated statement was used, with the period specified as the repeated variable. The covariance structure used in the analyses was autoregressive, which provided the best fit according to the Akaike information criterion. The subplot (the mean of three animals) was considered the experimental unit for daily ration intake, and the animal was considered the experimental unit for daily and average live weight gain, as well as for the carcass. As stated above, the model statement used for these analyses contained the effects of crop systems, yellow oat oversowing and their resultant interaction. A repeated statement was used, with the period specified as the repeated variable. The covariance structure used in the analyses was autoregressive, which provided the best fit according to the Akaike information criterion. The subplot data were analyzed using the animals and all data were analyzed using diets as the random variables. The results were reported as least squares means and separated by preplanned pairwise comparisons (PDIFF). Mean separations were conducted using LSD tests. The effects were considered statistically significant at $P \leq 0.05$. The results were reported as main effects if no interactions were significant or according to the highest-order interaction detected.

\section{Results}

Palisade grass (cv. Marandu) after a 0.45 -m cutting height of corn for silage presented a greater total pasture forage mass than that of weedy signal grass (Table 4). In the first and second 14 -d lamb grazing periods, the system with yellow oat oversowing increased the pasture forage mass, as reflected in the greater total pasture forage mass.

The greater competitive ability of palisade grass with yellow oat, primarily after being cut at $0.45 \mathrm{~m}$ for silage, increased the amount and proportion of palisade grass compared with signal grass in the first two 14-d lamb grazing periods, reducing the amount and proportion of yellow oat only in the first 14-d grazing period (Table 5).

In all crop systems, the daily ration intake was lower in the first period than that in the other 14-d grazing periods (Table 6 ). The daily ration intake by lambs was lower with palisade grass and a 0.45 -m cutting height for silage than that in other treatments during the second and third 14-d periods. This treatment also showed a lower daily ration intake in the second and third 14-d grazing periods than that in the fourth and fifth 14-d grazing periods. Yellow oat oversowing also reduced the daily ration intake in the first two 14-d grazing periods compared with no yellow oat oversowing and the other 14-d grazing periods.

The daily live weight gain, average live weight gain and total live weight gain of lambs in all of the 14-d periods were greatest with palisade grass at a 0.45 -m silage cutting height (Table 7 ). Oversowing of yellow oat did not influence the daily live weight gain, average live weight gain and total live weight gain of lambs in any of the 14-d grazing periods compared with the absence of yellow oat oversowing. The final live weight and final stocking rate of lambs were greatest with palisade grass at a $0.45-\mathrm{m}$ silage cutting height (Table 8 ).

Palisade grass with a $0.45-\mathrm{m}$ silage cutting height provided the greatest cold carcass weight of lambs (Table 9). Oversowing of yellow oat did not influence the cold carcass weight of lambs. The cold carcass yield and subcutaneous fat cover score were not influenced by any of the treatments.

The cold carcass weight gain, revenue, and contribution margin were greatest with corn silage cut at a $0.45-\mathrm{m}$ height with palisade grass intercropped and oversown with yellow oat in both growing seasons (Table 10). This treatment also had the lowest total operating cost. The corn-only treatment (weedy regrowth of signal grass) with a 0.20 $m$ cutting height and without yellow oat oversowing provided the lowest contribution margin in the second growing season and in the sum of the two growing seasons, whereas in the first growing season, independent of yellow oat oversowing, this option was also the least feasible. Considering the two growing seasons, corn silage intercropped with palisade grass (cv. Piatã) at a 0.20 -m cutting height with or without yellow oat oversowing provided a greater economic return with extra silage than that of the corn-only treatment.

\section{Discussion}

\subsection{Weather conditions}

In the first growing season, a rainfall of $1894 \mathrm{~mm}$ was $39 \%$ greater than the historical average $(1359 \mathrm{~mm})$, and the mean annual temperature of $21.2{ }^{\circ} \mathrm{C}$ was similar to the historical average $\left(20.7^{\circ} \mathrm{C}\right)$. In the

Table 4

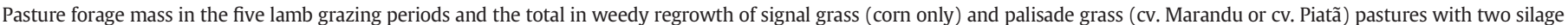
cutting heights with or without yellow oat oversowing (the mean of the two growing seasons).

\begin{tabular}{|c|c|c|c|c|c|c|c|}
\hline \multirow[t]{2}{*}{ Treatment } & \multirow[t]{2}{*}{ Cutting height $(\mathrm{m})$} & \multicolumn{6}{|l|}{ Period } \\
\hline & & $\mathrm{Mg} \mathrm{ha}^{-1}$ & 2 & 3 & 4 & 5 & Total \\
\hline \multicolumn{8}{|l|}{ Crop systems } \\
\hline Corn + weedy signal grass & 0.20 & $2.6 \mathrm{aA}^{\mathrm{a}}$ & $1.9 \mathrm{bB}$ & $0.9 \mathrm{cC}$ & $0.6 \mathrm{cD}$ & $0.4 \mathrm{dE}$ & $6.4 \mathrm{~d}$ \\
\hline Corn + weedy signal grass & 0.45 & $2.7 \mathrm{aA}$ & $1.9 \mathrm{bB}$ & $1.2 \mathrm{bC}$ & $0.8 \mathrm{bD}$ & $0.7 \mathrm{cD}$ & $7.3 \mathrm{c}$ \\
\hline Corn + palisade grass cv. Piatã & 0.20 & $2.9 \mathrm{aA}$ & $2.0 \mathrm{bB}$ & $1.3 \mathrm{bC}$ & $1.0 \mathrm{bD}$ & $0.8 \mathrm{cD}$ & $8.0 \mathrm{c}$ \\
\hline Corn + palisade grass cv. Piatã & 0.45 & $2.9 \mathrm{aA}$ & $2.5 \mathrm{aB}$ & $1.6 \mathrm{aC}$ & $1.3 \mathrm{aD}$ & $1.1 \mathrm{bE}$ & $9.4 \mathrm{~b}$ \\
\hline Corn + palisade grass cv. Marandu & 0.20 & $3.0 \mathrm{aA}$ & $1.9 \mathrm{bB}$ & $1.0 \mathrm{cC}$ & $0.9 \mathrm{bC}$ & $0.7 \mathrm{cD}$ & $7.5 \mathrm{c}$ \\
\hline Corn + palisade grass cv. Marandu & 0.45 & $3.2 \mathrm{aA}$ & $2.3 \mathrm{aB}$ & $1.8 \mathrm{aC}$ & $1.5 \mathrm{aC}$ & $1.6 \mathrm{aC}$ & $10.4 \mathrm{a}$ \\
\hline Standard errors & - & 0.40 & 0.35 & 0.32 & 0.32 & 0.31 & 0.93 \\
\hline \multicolumn{8}{|l|}{ Yellow oat oversowing } \\
\hline With & - & $3.7 \mathrm{aA}^{\mathrm{a}}$ & $2.7 \mathrm{aB}$ & $1.3 \mathrm{aC}$ & $1.1 \mathrm{aC}$ & $1.2 \mathrm{bC}$ & $10.0 \mathrm{a}$ \\
\hline Without & - & $2.0 \mathrm{bA}$ & $1.5 \mathrm{bB}$ & $1.3 \mathrm{aC}$ & $1.0 \mathrm{aD}$ & $0.6 \mathrm{aE}$ & $6.4 \mathrm{~b}$ \\
\hline Standard errors & - & 0.34 & 0.32 & 0.31 & 0.31 & 0.31 & 1.34 \\
\hline
\end{tabular}

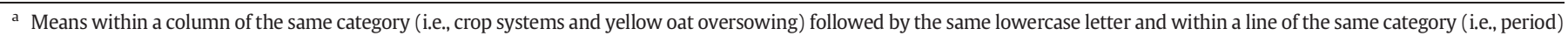
followed by the same uppercase letter are not significantly different at $P \leq 0.05$. 
Table 5

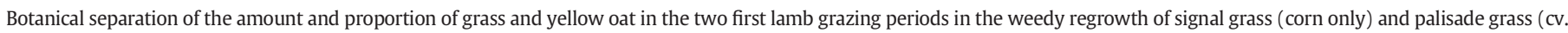
Marandu or cv. Piatã) pastures with two silage cutting heights in the two growing seasons.

\begin{tabular}{|c|c|c|c|c|c|c|c|c|c|}
\hline \multirow[t]{3}{*}{ Treatment } & \multirow[t]{3}{*}{ Cutting height (m) } & \multicolumn{4}{|l|}{ Period 1} & \multicolumn{4}{|l|}{ Period 2} \\
\hline & & \multicolumn{2}{|l|}{ Grass } & \multicolumn{2}{|l|}{ Yellow oat } & \multicolumn{2}{|l|}{ Grass } & \multicolumn{2}{|c|}{ Yellow oat } \\
\hline & & $\mathrm{Mg} \mathrm{ha}^{-1}$ & $\%$ & $\mathrm{Mg} \mathrm{ha}^{-1}$ & $\%$ & $\mathrm{Mg} \mathrm{ha}^{-1}$ & $\%$ & $\mathrm{Mg} \mathrm{ha}^{-1}$ & $\%$ \\
\hline \multicolumn{10}{|l|}{ Crop systems } \\
\hline Corn + weedy signal grass & 0.20 & $2.0 c^{a}$ & $52.6 \mathrm{~d}$ & $1.8 \mathrm{a}$ & $47.4 \mathrm{a}$ & $1.6 \mathrm{c}$ & $76.2 \mathrm{a}$ & $0.5 \mathrm{a}$ & $23.8 \mathrm{a}$ \\
\hline Corn + weedy signal grass & 0.45 & $2.0 \mathrm{c}$ & $60.1 \mathrm{c}$ & $1.3 \mathrm{~b}$ & $39.9 \mathrm{~b}$ & $1.9 \mathrm{~b}$ & $79.2 \mathrm{a}$ & $0.5 \mathrm{a}$ & $20.8 \mathrm{a}$ \\
\hline Corn + palisade grass cv. Piatã & 0.20 & $2.5 \mathrm{~b}$ & $67.6 \mathrm{~b}$ & $1.2 \mathrm{~b}$ & $32.4 \mathrm{~b}$ & $2.1 \mathrm{~b}$ & $77.8 \mathrm{a}$ & $0.6 \mathrm{a}$ & $22.2 \mathrm{a}$ \\
\hline Corn + palisade grass cv. Piatã & 0.45 & $2.8 \mathrm{a}$ & $75.7 \mathrm{a}$ & $0.9 \mathrm{c}$ & $24.3 c$ & $2.5 \mathrm{a}$ & $83.3 \mathrm{a}$ & $0.5 \mathrm{a}$ & $16.7 \mathrm{a}$ \\
\hline Corn + palisade grass cv. Marandu & 0.20 & $2.4 \mathrm{~b}$ & $61.5 c$ & $1.5 \mathrm{~b}$ & $38.5 \mathrm{~b}$ & $2.1 \mathrm{~b}$ & $84.0 \mathrm{a}$ & $0.4 \mathrm{a}$ & $16.0 \mathrm{a}$ \\
\hline Corn + palisade grass cv. Marandu & 0.45 & $2.8 \mathrm{a}$ & $73.7 \mathrm{a}$ & $1.0 \mathrm{c}$ & $26.3 c$ & $2.7 \mathrm{a}$ & $84.4 \mathrm{a}$ & $0.5 \mathrm{a}$ & $15.6 \mathrm{a}$ \\
\hline Standard errors & - & 0.22 & 4.17 & 0.21 & 4.17 & 0.19 & 3.85 & 0.10 & 3.85 \\
\hline \multicolumn{10}{|l|}{ Growing seasons } \\
\hline First (2010-2011) & - & $1.9 \mathrm{~b}^{\S}$ & $65.5 \mathrm{a}$ & $1.0 \mathrm{~b}$ & $34.5 \mathrm{a}$ & $1.8 \mathrm{~b}$ & $85.7 \mathrm{a}$ & $0.3 \mathrm{~b}$ & $14.3 \mathrm{~b}$ \\
\hline Second (2011-2012) & - & $3.0 \mathrm{a}$ & $66.7 \mathrm{a}$ & $1.5 \mathrm{a}$ & $33.3 \mathrm{a}$ & $2.5 \mathrm{a}$ & $78.1 \mathrm{~b}$ & $0.7 \mathrm{a}$ & $21.9 \mathrm{a}$ \\
\hline Standard errors & - & 0.13 & 2.41 & 0.12 & 2.41 & 0.11 & 2.22 & 0.06 & 2.22 \\
\hline
\end{tabular}

${ }^{\text {a }}$ Means within a column of the same category (i.e., crop systems and growing seasons) followed by the same letter are not significantly different at $P \leq 0.05$.

second growing season, the rainfall was $1896 \mathrm{~mm}$, and the mean annual temperature was $22.2^{\circ} \mathrm{C}$.

Between harvesting of corn for silage and stocking of lambs on pasture, a rainfall of 125 and $513 \mathrm{~mm}$ occurred in the first and second growing seasons, respectively, and after yellow oat oversowing, a rainfall of 82 and $254 \mathrm{~mm}$ occurred in the first and second growing seasons, respectively. The minimum temperature between May and July was lower in the first growing season than that in the second growing season. Moreover, minimum temperatures of $2.8,2.8$, and $2.4{ }^{\circ} \mathrm{C}$ on 28 June 2011 and 4-5 August 2011, respectively, were unusually cold for this region in Brazil.

\subsection{Forage mass of pasture}

The greater competitive strength and shade adaptability of palisade grass than that of signal grass were reflected in better pasture formation in winter/spring (Table 4). Although the pasture forage mass was not influenced by crop systems in the first 14-d lamb grazing period, a higher cutting height of palisade grass caused less damage to intercropped forage, resulting in a greater total pasture forage mass during the subsequent 14-d grazing periods.

In both growing seasons, yellow oat produced inflorescences prior to grazing; therefore, regrowth did not occur in shoot apical meristem after removal by grazing (Gerdes et al., 2005). Thus, yellow oat availability was restricted only to the first two 14-d lamb grazing periods.
However, yellow oat oversowing was sufficient to significantly increase the total pasture forage mass. Due to the absence of yellow oat regrowth, dry matter availability in the second 14-d lamb grazing period was simply the remainder from the first 14-d grazing period. Therefore, grasses were not competing with yellow oat.

Better weather conditions in the second growing season (Table 1) favored the growth of Urochloa grasses and yellow oat, which had greater dry matter in the first two 14-d grazing periods than that later. The ideal temperature range for the development of both palisade grass and signal grass is between 30 and $35^{\circ} \mathrm{C}$, and at temperatures between 10 and $15^{\circ} \mathrm{C}$, the growth is virtually non-existent (Costa et al., 2005). Combined with low rainfall from May to September, the development of these grasses was limited, particularly in the first growing season.

Over the five 14-d lamb grazing periods, the pasture forage mass in all crop systems decreased (Table 4). By the third 14-d lamb grazing period, some crop systems reached a pasture forage mass of $<1.2 \mathrm{Mg} \mathrm{ha}^{-1}$, which is the minimum acceptable pasture forage mass for cutting or intake by grazing ruminants (Mott, 1980). There was acceptable pasture forage mass over the five 14 -d lamb grazing periods with a 0.45 -m silage height and intercropping with palisade grass only. These results demonstrate the difficulty of using the other four crop systems because they may compromise grazing intake behavior and the performance of lambs.

The rapid reduction of pasture forage mass in some crop systems (Table 4) can also compromise soil mulch cover and quantity, thereby limiting the suitability for NTS (Pariz et al., 2016). Proper grazing

Table 6

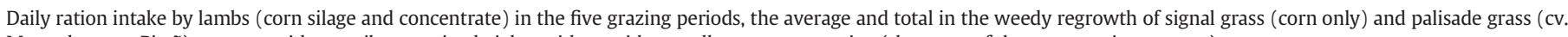
Marandu or cv. Piatã) pastures with two silage cutting heights with or without yellow oat oversowing (the mean of the two growing seasons).

\begin{tabular}{|c|c|c|c|c|c|c|c|c|}
\hline \multirow[t]{3}{*}{ Treatment } & \multirow[t]{3}{*}{ Cutting height (m) } & \multicolumn{5}{|c|}{ Daily ration intake (\% of live weight) } & \multirow{3}{*}{$\begin{array}{l}\text { Average daily ration intake } \\
\% \text { of live weight }\end{array}$} & \multirow{3}{*}{$\begin{array}{l}\text { Total daily ration intake } \\
\mathrm{kg} \cdot \text { animal }^{-1}\end{array}$} \\
\hline & & \multicolumn{5}{|l|}{ Period } & & \\
\hline & & 1 & 2 & 3 & 4 & 5 & & \\
\hline \multicolumn{9}{|l|}{ Crop systems } \\
\hline Corn + weedy signal grass & 0.20 & $2.0 \mathrm{aB}^{\mathrm{a}}$ & $2.7 \mathrm{aA}$ & $2.8 \mathrm{aA}$ & $2.7 \mathrm{aA}$ & $2.7 \mathrm{aA}$ & $2.6 \mathrm{a}$ & $49.0 \mathrm{a}$ \\
\hline Corn + weedy signal grass & 0.45 & $2.2 \mathrm{aB}$ & $2.7 \mathrm{aA}$ & $2.8 \mathrm{aA}$ & $2.7 \mathrm{aA}$ & $2.7 \mathrm{aA}$ & $2.6 \mathrm{a}$ & $50.8 \mathrm{a}$ \\
\hline Corn + palisade grass cv. Piatã & 0.20 & $2.2 \mathrm{aB}$ & $2.7 \mathrm{aA}$ & $2.8 \mathrm{aA}$ & $2.8 \mathrm{aA}$ & $2.7 \mathrm{aA}$ & $2.6 \mathrm{a}$ & $49.5 \mathrm{a}$ \\
\hline Corn + palisade grass cv. Piatã & 0.45 & $2.0 \mathrm{aC}$ & $2.3 \mathrm{bB}$ & $2.4 \mathrm{bB}$ & $2.7 \mathrm{aA}$ & $2.7 \mathrm{aA}$ & $2.4 \mathrm{~b}$ & $47.9 \mathrm{~b}$ \\
\hline Corn + palisade grass cv. Marandu & 0.20 & $2.2 \mathrm{aB}$ & $2.7 \mathrm{aA}$ & $2.8 \mathrm{aA}$ & $2.8 \mathrm{aA}$ & $2.7 \mathrm{aA}$ & $2.6 \mathrm{a}$ & $49.9 \mathrm{a}$ \\
\hline Corn + palisade grass cv. Marandu & 0.45 & $2.0 \mathrm{aC}$ & $2.3 \mathrm{bB}$ & $2.4 \mathrm{bB}$ & $2.7 \mathrm{aA}$ & $2.7 \mathrm{aA}$ & $2.4 \mathrm{~b}$ & $48.2 \mathrm{~b}$ \\
\hline Standard errors & - & 0.09 & 0.07 & 0.07 & 0.11 & 0.06 & 0.07 & 1.7 \\
\hline \multicolumn{9}{|l|}{ Yellow oat oversowing } \\
\hline With & - & $1.8 \mathrm{bC}^{\mathrm{a}}$ & $2.3 \mathrm{bB}$ & $2.7 \mathrm{aA}$ & $2.7 \mathrm{aA}$ & $2.7 \mathrm{aA}$ & $2.4 \mathrm{~b}$ & $46.5 \mathrm{~b}$ \\
\hline Without & - & $2.6 \mathrm{aA}$ & $2.8 \mathrm{aA}$ & $2.7 \mathrm{aA}$ & $2.7 \mathrm{aA}$ & $2.7 \mathrm{aA}$ & $2.7 \mathrm{a}$ & 52.7 a \\
\hline Standard errors & - & 0.06 & 0.04 & 0.04 & 0.04 & 0.04 & 0.07 & 1.3 \\
\hline
\end{tabular}

${ }^{a}$ Means within a column of the same category (i.e., crop systems and yellow oat oversowing) followed by the same lowercase letter and within a line of the same category (i.e., period) followed by the same uppercase letter are not significantly different at $P \leq 0.05$. 
Table 7

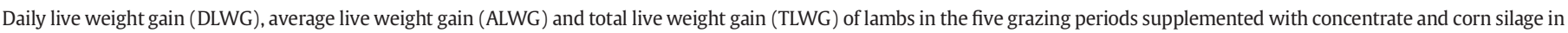

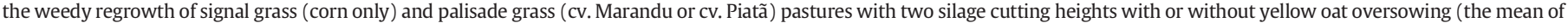
the two growing seasons).

\begin{tabular}{|c|c|c|c|c|c|c|c|c|}
\hline \multirow[t]{3}{*}{ Treatment } & \multirow[t]{3}{*}{ Cutting height $(\mathrm{m})$} & \multicolumn{5}{|c|}{ DLWG $\left(\mathrm{g} \cdot \mathrm{animal}^{-1} \mathrm{day}^{-1}\right)$} & \multirow{3}{*}{$\begin{array}{l}\text { ALWG } \\
\mathrm{g} \cdot \text { animal }^{-1} \text { day }^{-1}\end{array}$} & \multirow{3}{*}{$\begin{array}{l}\text { TLWG } \\
\mathrm{kg} \cdot \text { animal }^{-1}\end{array}$} \\
\hline & & \multicolumn{5}{|l|}{ Period } & & \\
\hline & & 1 & 2 & 3 & 4 & 5 & & \\
\hline \multicolumn{9}{|l|}{ Crop systems } \\
\hline Corn + weedy signal grass & 0.20 & $177 \mathrm{bA}^{\mathrm{a}}$ & $138 \mathrm{cB}$ & $130 \mathrm{cB}$ & $97 \mathrm{dC}$ & $190 \mathrm{cA}$ & $146 \mathrm{c}$ & $10.2 \mathrm{c}$ \\
\hline Corn + weedy signal grass & 0.45 & 179 bA & $131 \mathrm{cB}$ & $144 \mathrm{bB}$ & $110 \mathrm{cC}$ & $190 \mathrm{cA}$ & $151 \mathrm{c}$ & $10.6 \mathrm{c}$ \\
\hline Corn + palisade grass cv. Piatã & 0.20 & $173 \mathrm{bA}$ & $167 \mathrm{bB}$ & $132 \mathrm{cC}$ & $114 \mathrm{cD}$ & $179 \mathrm{dA}$ & $153 c$ & $10.7 \mathrm{c}$ \\
\hline Corn + palisade grass cv. Piatã & 0.45 & $177 \mathrm{bB}$ & $184 \mathrm{aB}$ & $152 \mathrm{bc}$ & $128 \mathrm{bD}$ & $211 \mathrm{bA}$ & $170 \mathrm{~b}$ & $11.9 \mathrm{~b}$ \\
\hline Corn + palisade grass cv. Marandu & 0.20 & $178 \mathrm{bB}$ & $164 \mathrm{bA}$ & $124 \mathrm{cD}$ & $124 \mathrm{bD}$ & $191 \mathrm{cA}$ & $156 \mathrm{c}$ & $10.9 \mathrm{c}$ \\
\hline Corn + palisade grass cv. Marandu & 0.45 & $191 \mathrm{aB}$ & $188 \mathrm{aB}$ & $182 \mathrm{aB}$ & $157 \mathrm{aC}$ & $225 \mathrm{aA}$ & $189 \mathrm{a}$ & $13.2 \mathrm{a}$ \\
\hline Standard errors & - & 8.9 & 8.3 & 8.3 & 8.1 & 8.4 & 8.4 & 0.9 \\
\hline \multicolumn{9}{|l|}{ Yellow oat oversowing } \\
\hline With & - & $181 \mathrm{aB}^{\S}$ & $162 \mathrm{aC}$ & $144 \mathrm{aD}$ & $122 \mathrm{aE}$ & $198 \mathrm{aA}$ & $161 \mathrm{a}$ & $11.3 \mathrm{a}$ \\
\hline Without & - & $180 \mathrm{aB}$ & $161 \mathrm{aC}$ & $143 \mathrm{aD}$ & $120 \mathrm{aE}$ & $198 \mathrm{aA}$ & $160 \mathrm{a}$ & $11.2 \mathrm{a}$ \\
\hline Standard errors & - & 7.8 & 7.5 & 7.5 & 7.5 & 7.6 & 7.6 & 0.7 \\
\hline
\end{tabular}

a Means within a column of the same category (i.e., crop systems and yellow oat oversowing) followed by the same lowercase letter and within a line of the same category (i.e., period) followed by the same uppercase letter are not significantly different at $P \leq 0.05$.

management is an essential factor for the success of ICLS, and additional studies are needed to evaluate the optimum grazing intensity, stocking rate (fixed or variable), and grazing method (continuous or rotational) on mulch cover, surface mulch quantity, and long-term system sustainability (Barth Neto et al., 2014; Savian et al., 2014). Pastures with excessive grazing have low leaf area index, compromising the interception of solar radiation by the canopy, with a consequent reduction in net photosynthesis and impairment of regrowth (Balbinot Júnior et al., 2009). Low ground cover with excessive grazing enables weed infestation and water erosion. Neither of these problems was observed in palisade grass when silage was harvested at a $0.45-\mathrm{m}$ height.

\subsection{Daily ration intake (corn silage and concentrate) by lambs}

Differences in daily ration intake could be attributed to the pasture forage mass (Tables 4 and 5), wherein treatments with the greatest pasture forage mass had the lowest daily ration intake (Table 6). With advanced physiological stage, the concentrations of non-fiber carbohydrates, total digestible nutrients and crude protein are reduced, and the concentrations of silica, lignin and fiber are increased, thereby reducing the nutritional value and intake of forage (Silva and Queiroz, 2002). Thus, the development of the flowering of yellow oat plants likely reduced the nutritional value (Barro et al., 2008). However, a pasture forage mass of $>1.0 \mathrm{Mg}$ with palisade grass at a $0.45-\mathrm{m}$ silage cutting height and yellow oat oversowing appeared to allow the lambs to consume a greater quantity of pasture and reduce ration intake in all 14-d grazing periods.
The daily ration intake over 70 days of the semi-feedlot system was 0.664 and $0.753 \mathrm{~kg}$ animal $^{-1}$ day $^{-1}$ with and without yellow oat oversowing, respectively. The average daily ration intake was $2.4-2.7 \%$ of live weight (Table 6). This amount is considered to be sufficiently lower than the daily ration intake of $4.3-5.1 \%$ of live weight and 1.274 and $1.573 \mathrm{~kg}$ animal $^{-1} \mathrm{day}^{-1}$ for Santa Inês lambs in a feedlot system with a daily live weight gain (DLWG) of 172-219 g (Parente et al., 2009). Therefore, the semi-feedlot method of lamb finishing with ICLS in this study produced a similar DLWG and a lower daily ration intake of corn silage and concentrate compared with lambs finished in a pure feedlot.

\subsection{Live weight gain by lambs and stocking rate on the pasture}

The daily live weight gain and average live weight gain of lambs in all crop systems and in all 14-d grazing periods were $>100 \mathrm{~g}$, as estimated by NRC (2007) (Table 7). These results suggest that the dry matter intake from the pasture was greater than the assumed $0.50 \%$ of live weight from the Cornell Net Carbohydrate and Protein System (2000). A greater availability of palisade grass forage with a longer silage cutting height contributed to the greater daily live weight gain and total live weight gain of lambs, above that from a standard amount of corn silage and concentrate.

The results of this study demonstrate that yellow oat oversowing can reduce the daily ration intake and the feed cost to achieve a similar live weight gain (Table 7). The lower daily live weight gain in the fourth

Table 8

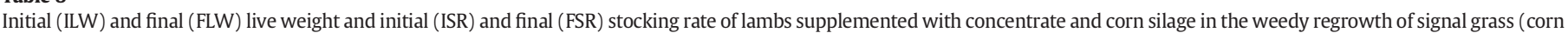
only) and palisade grass (cv. Marandu or cv. Piatã) pastures with two silage cutting heights with or without yellow oat oversowing (the mean of the two growing seasons).

\begin{tabular}{|c|c|c|c|c|c|}
\hline Treatment & Cutting height $(\mathrm{m})$ & $\begin{array}{l}\text { ILW } \\
\mathrm{kg} \cdot \text { animal }^{-1}\end{array}$ & FLW & $\begin{array}{l}\text { ISR } \\
\mathrm{Mg} \mathrm{ha}^{-1} \text { of live weight }\end{array}$ & FSR \\
\hline \multicolumn{6}{|l|}{ Crop systems } \\
\hline Corn + weedy signal grass & 0.20 & $21.8 \mathrm{a}^{\mathrm{a}}$ & $32.0 \mathrm{~d}$ & $2.9 \mathrm{a}$ & $4.3 \mathrm{c}$ \\
\hline Corn + weedy signal grass & 0.45 & $22.6 \mathrm{a}$ & $33.2 \mathrm{c}$ & $3.0 \mathrm{a}$ & $4.4 \mathrm{c}$ \\
\hline Corn + palisade grass cv. Piatã & 0.20 & $21.8 \mathrm{a}$ & $32.5 \mathrm{c}$ & $2.9 \mathrm{a}$ & $4.3 \mathrm{c}$ \\
\hline Corn + palisade grass cv. Piatã & 0.45 & $22.5 \mathrm{a}$ & $34.4 \mathrm{~b}$ & $3.0 \mathrm{a}$ & $4.6 \mathrm{~b}$ \\
\hline Corn + palisade grass cv. Marandu & 0.20 & $21.9 \mathrm{a}$ & $32.8 \mathrm{c}$ & $2.9 \mathrm{a}$ & $4.4 \mathrm{c}$ \\
\hline Corn + palisade grass cv. Marandu & 0.45 & $22.1 \mathrm{a}$ & $35.3 \mathrm{a}$ & $2.9 \mathrm{a}$ & $4.7 \mathrm{a}$ \\
\hline Standard errors & - & 0.99 & 0.76 & 0.13 & 0.08 \\
\hline \multicolumn{6}{|l|}{ Yellow oat oversowing } \\
\hline With & - & $22.0 \mathrm{a}^{\mathrm{a}}$ & $33.3 \mathrm{a}$ & $2.9 \mathrm{a}$ & $4.4 \mathrm{a}$ \\
\hline Without & - & $22.3 \mathrm{a}$ & $33.5 \mathrm{a}$ & $3.0 \mathrm{a}$ & $4.5 \mathrm{a}$ \\
\hline Standard errors & - & 0.64 & 0.71 & 0.84 & 0.13 \\
\hline
\end{tabular}

\footnotetext{
a Means within a column of the same category (i.e., crop systems and yellow oat oversowing) followed by the same letter are not significantly different at $P \leq 0.05$.
} 
Table 9

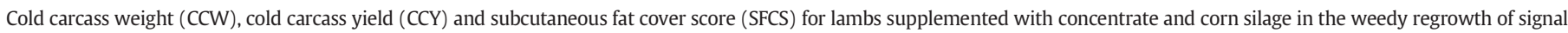
grass (corn only) and palisade grass (cv. Marandu or cv. Piatã) pastures with two silage cutting heights with or without yellow oat oversowing (the mean of two growing seasons).

\begin{tabular}{|c|c|c|c|c|}
\hline Treatment & Cutting height $(\mathrm{m})$ & $\begin{array}{l}\mathrm{CCW} \\
\mathrm{kg} \cdot \text { animal }^{-1}\end{array}$ & $\begin{array}{l}\mathrm{CCY} \\
\%\end{array}$ & $\begin{array}{l}\text { SFCS } \\
\text { Scale }(1-5)\end{array}$ \\
\hline \multicolumn{5}{|l|}{ Crop systems } \\
\hline Corn + weedy signal grass & 0.20 & $15.2 c^{a}$ & $47.5 \mathrm{a}$ & $2.2 \mathrm{a}$ \\
\hline Corn + weedy signal grass & 0.45 & $15.8 \mathrm{c}$ & $47.6 \mathrm{a}$ & $2.2 \mathrm{a}$ \\
\hline Corn + palisade grass cv. Piatã & 0.20 & $15.4 \mathrm{c}$ & $47.5 \mathrm{a}$ & $2.2 \mathrm{a}$ \\
\hline Corn + palisade grass cv. Piatã & 0.45 & $16.6 \mathrm{~b}$ & $48.5 \mathrm{a}$ & $2.2 \mathrm{a}$ \\
\hline Corn + palisade grass cv. Marandu & 0.20 & $15.8 \mathrm{c}$ & $48.3 \mathrm{a}$ & $2.2 \mathrm{a}$ \\
\hline Corn + palisade grass cv. Marandu & 0.45 & $17.0 \mathrm{a}$ & $48.2 \mathrm{a}$ & $2.2 \mathrm{a}$ \\
\hline Standard errors & - & 0.32 & 0.96 & 0.72 \\
\hline \multicolumn{5}{|l|}{ Yellow oat oversowing } \\
\hline With & - & $15.2 \mathrm{a}^{\mathrm{a}}$ & $47.9 \mathrm{a}$ & $2.2 \mathrm{a}$ \\
\hline Without & - & $15.5 \mathrm{a}$ & $48.0 \mathrm{a}$ & $2.2 \mathrm{a}$ \\
\hline Standard errors & - & 0.47 & 0.87 & 0.72 \\
\hline
\end{tabular}

\footnotetext{
a Means within a column of the same category (i.e., crop systems and yellow oat oversowing) followed by the same letter are not significantly different at $P \leq 0.05$.
}

Table 10

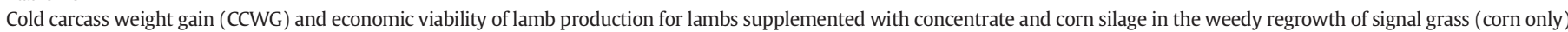
and palisade grass (cv. Marandu or cv. Piatã) pastures with two silage cutting heights with or without yellow oat oversowing in two growing seasons.

\begin{tabular}{|c|c|c|c|c|c|}
\hline Treatment $^{\mathrm{a}}$ & $\begin{array}{l}\text { CCWG } \\
\mathrm{kg} \mathrm{ha}^{-1}\end{array}$ & $\begin{array}{l}\text { Revenue }^{\mathrm{b}} \\
\text { US\$ ha }\end{array}$ & $\begin{array}{l}\text { TOC }^{\mathrm{C}} \\
\text { US\$ ha }\end{array}$ & $\begin{array}{l}\mathrm{CM}^{\mathrm{d}} \\
\mathrm{US} \$ \mathrm{ha}^{-1}\end{array}$ & $\begin{array}{l}\text { Extra silage } \\
\text { US\$ ha } \\
\text { e-1 }\end{array}$ \\
\hline \multicolumn{6}{|l|}{ Crop systems } \\
\hline$C+S 0.20-$ with yellow oat & 625 & 3070 & 2728 & 342 & 912 \\
\hline$C+$ S 0.45 - with yellow oat & 682 & 3349 & 2813 & 536 & 866 \\
\hline$C+$ P 0.20 - with yellow oat & 690 & 3387 & 2590 & 797 & 1065 \\
\hline$C+$ P 0.45 - with yellow oat & 726 & 3564 & 2577 & 988 & 1063 \\
\hline $\mathrm{C}+\mathrm{M} 0.20-$ with yellow oat & 720 & 3536 & 2742 & 794 & 1008 \\
\hline $\mathrm{C}+\mathrm{M} 0.45$ - with yellow oat & 787 & 3861 & 2638 & 1223 & 975 \\
\hline$C+$ S 0.20 - without yellow oat & 616 & 3023 & 2679 & 343 & 905 \\
\hline$C+$ S 0.45 - without yellow oat & 669 & 3284 & 2741 & 543 & 859 \\
\hline$C+P 0.20$ - without yellow oat & 666 & 3271 & 2687 & 584 & 1044 \\
\hline$C+$ P 0.45 - without yellow oat & 714 & 3506 & 2477 & 1029 & 1063 \\
\hline$C+$ M 0.20 - without yellow oat & 672 & 3297 & 2698 & 599 & 1000 \\
\hline$C+$ M 0.45 - without yellow oat & 729 & 3577 & 2668 & 910 & 961 \\
\hline \multicolumn{6}{|l|}{ Second growing season } \\
\hline$C+S 0.20$ - with yellow oat & 833 & 4768 & 2956 & 1812 & 969 \\
\hline$C+S 0.45-$ with yellow oat & 850 & 4868 & 3090 & 1778 & 839 \\
\hline$C+$ P 0.20 - with yellow oat & 842 & 4821 & 3163 & 1658 & 978 \\
\hline$C+$ P 0.45 - with yellow oat & 853 & 4883 & 3149 & 1734 & 932 \\
\hline $\mathrm{C}+\mathrm{M} 0.20$ - with yellow oat & 859 & 4920 & 3221 & 1699 & 944 \\
\hline $\mathrm{C}+\mathrm{M} 0.45$ - with yellow oat & 1000 & 5727 & 2992 & 2736 & 942 \\
\hline$C+S 0.20$ - without yellow oat & 795 & 4555 & 3079 & 1476 & 931 \\
\hline$C+S 0.45$ - without yellow oat & 827 & 4737 & 3211 & 1526 & 795 \\
\hline$C+$ P 0.20 - without yellow oat & 819 & 4692 & 3016 & 1676 & 994 \\
\hline$C+P 0.45$ - without yellow oat & 885 & 5066 & 3174 & 1893 & 909 \\
\hline$C+$ M 0.20 - without yellow oat & 833 & 4768 & 2961 & 1807 & 982 \\
\hline$C+$ M 0.45 - without yellow oat & 905 & 5180 & 3153 & 2027 & 893 \\
\hline \multicolumn{6}{|l|}{ Sum of the two growing seasons } \\
\hline$C+S 0.20$ - with yellow oat & 1458 & 7837 & 5684 & 2153 & 1882 \\
\hline$C+S 0.45-$ with yellow oat & 1532 & 8217 & 5903 & 2314 & 1705 \\
\hline$C+$ P 0.20 - with yellow oat & 1532 & 8208 & 5753 & 2455 & 2043 \\
\hline$C+$ P 0.45 - with yellow oat & 1579 & 8447 & 5726 & 2722 & 1995 \\
\hline $\mathrm{C}+\mathrm{M} 0.20$ - with yellow oat & 1579 & 8456 & 5955 & 2493 & 1952 \\
\hline $\mathrm{C}+\mathrm{M} 0.45-$ with yellow oat & 1787 & 9588 & 5629 & 3959 & 1917 \\
\hline$C+$ S 0.20 - without yellow oat & 1411 & 7577 & 5758 & 1819 & 1836 \\
\hline$C+$ S 0.45 - without yellow oat & 1496 & 8021 & 5952 & 2069 & 1653 \\
\hline$C+P 0.20$ - without yellow oat & 1486 & 7962 & 5703 & 2260 & 2038 \\
\hline$C+P 0.45$ - without yellow oat & 1599 & 8573 & 5651 & 2922 & 1972 \\
\hline $\mathrm{C}+\mathrm{M} 0.20$ - without yellow oat & 1504 & 8065 & 5659 & 2405 & 1981 \\
\hline$C+$ M 0.45 - without yellow oat & 1633 & 8757 & 5820 & 2937 & 1854 \\
\hline
\end{tabular}

${ }^{a} \mathrm{C}+\mathrm{S}, \mathrm{C}+\mathrm{P}$ and $\mathrm{C}+\mathrm{M}$ : corn only (with weedy regrowth of signal grass), corn intercropped with palisade grass cv. Piatã and corn intercropped with palisade grass cv. Marandu, respectively; 0.20 and 0.45 : corn silage cutting heights ( 0.20 and $0.45 \mathrm{~m}$ above the soil surface, respectively).

b Revenue with the sale of cold lamb carcasses. Average selling price of cold lamb carcasses in São Paulo, Brazil was US\$ 4.90 and US\$ 5.72 in the first and second growing seasons, respectively, depending on the different subcutaneous fat cover scores of the lamb carcasses.

c TOC: total operating cost with operations and inputs, including interest of $6 \%$ per year on capital.

d CM: contribution margin [revenue with sale of lamb carcasses minus the total operating cost (TOC)]

e Value of silage produced and not consumed by lambs, considering the TOC per kg of dry matter. 
14-d grazing period than that in the other periods may have been due to the excess precipitation (Table 1 ) that reduced the grazing time of lambs.

The initial and final stocking rates were $2.9-3.0$ and $4.3-4.7 \mathrm{Mg} \mathrm{ha}^{-1}$ of live weight, respectively. The number of lambs ha ${ }^{-1}$ in this study (133 lambs ha ${ }^{-1}$ ) was extremely high compared with those reported by Macedo et al. (2000), Carnevalli et al. (2001) and Ribeiro et al. (2009) under a continuous stocking rate and those reported by Poli et al. (2008) and Piazzetta et al. (2009) under a variable stocking rate for sheep grazing. However, a high stocking rate was achieved by supplementing lambs with corn silage and concentrate in a semi-feedlot system.

\subsection{Cold carcass weight and yield of lambs}

The carcass weight and yield are influenced by growth rate, age at slaughter, and nutritional management. The cold carcass yield ranged from 40 to $50 \%$, as described by Silva Sobrinho (2001) for specialized lamb meat breeds. The cold carcass weight and cold carcass yield were similar to the values of $14.8-15.6 \mathrm{~kg}$ and $47.3-49.0 \%$, respectively, reported by Moreno et al. (2010), who evaluated diets with roughage:concentrate ratios of $40: 60$ and $60: 40$ using sugarcane or corn silage, respectively, in a feedlot of Ile de France lambs slaughtered at $32 \mathrm{~kg}$ of live weight. However, Parente et al. (2009) reported a cold carcass weight and cold carcass yield of $12.9-15.0 \mathrm{~kg}$ and $38.6-41.0 \%$, respectively, for Santa Inês lambs slaughtered at $35.2 \mathrm{~kg}$ of live weight. The results obtained in this study for cold carcass weight and cold carcass yield can be considered satisfactory.

\subsection{Subcutaneous fat cover score of the lamb carcasses}

Subcutaneous fat and muscularity are important qualitative characteristics for carcass classification systems (Silva Sobrinho, 2001). The subcutaneous fat cover score was greater in the second than in the first growing season, which may have occurred from increased energy in the diet due to a greater proportion of grain in the silage. The forage harvester crushed silage corn grains in the second growing season, which may have increased starch availability, providing greater energy availability to animals (Weiss and Wyatt, 2000) and increasing the subcutaneous fat cover score.

The subcutaneous fat cover score of 2.9 in the second growing season indicates good fat cover in lamb carcasses, reflecting better animal finishing. Fat accumulation follows different development models, and for each animal genotype, an optimal age and slaughter weight exist. Some slaughterhouses remunerate carcasses with higher subcutaneous fat cover because this fat serves as a thermal insulator, reducing the cooling rate, reducing the risk of the cold shortening of muscle fibers, and improving the organoleptic properties of the meat (Osório et al., 2002). Tissues develop at different rates throughout the life of the animal. Bone tissue exhibits early growth, muscle tissue has intermediate growth, and fat tissue has slow growth (Medeiros et al., 2011). The nutritional level of the animal can influence subcutaneous fat deposition (Rosa et al., 2002). Thus, in the first growing season, the energy in the diet may have been used for muscle deposition, leaving a reduced amount of energy for subcutaneous fat deposition.

\subsection{Economic viability}

In the first growing season, the production cost of corn silage was US\$ $83.75 \mathrm{ha}^{-1}$ higher than that in the second growing season due to inputs and operations used in the initial preparation of the area. Corn seeds and mineral fertilizers represented the highest input costs. In the second growing season, mineral fertilizer was the greatest input cost; thus, price fluctuations of mineral fertilizer among the years studied can influence the economic outcomes of the systems under investigation.
The feasibility of recovering degraded pastures using ICLS with a cost increase of only US\$ $51.87 \mathrm{ha}^{-1}$ for the acquisition of palisade grass $\mathrm{cv}$. Marandu or cv. Piatã seeds was investigated. In Brazil, the total operating costs for the recovery of degraded pastures using palisade grass cultivars are approximately US\$ $1073.72 \mathrm{ha}^{-1}$ (Anualpec, 2016). The production cost of corn silage in this study, considering a $5 \%$ loss in the silage process and in the removal of silage from the silo, was US\$ $0.07-0.11 \mathrm{~kg}^{-1} \mathrm{dry}$ matter. In general, the production costs were similar to the corn silage cost of US $\$ 0.09 \mathrm{~kg}^{-1}$ dry matter reported by Anualpec (2016) in Brazil.

The greater pasture forage mass (Table 4), daily live weight gain (Table 7) and cold carcass weight (Tables 9 and 10) throughout the 14-d lamb grazing periods indicated that corn silage intercropped with palisade grass and with a $0.45-\mathrm{m}$ silage cutting height with yellow oat oversowing provided the best economic results (Table 10). The dependence on the weedy regrowth of volunteer signal grass (corn only) from the soil seed bank combined with a 0.20 -m cutting height of corn silage and no yellow oat oversowing provided the lowest economic return. Yokoyama et al. (1999), Tracy and Zhang (2008), Pariz et al. (2009), Crusciol et al. (2012), Borghi et al. (2013a), and Crusciol et al. (2014) also found positive economic results using ICLS for corn intercropped with palisade grass cultivars. Currently, the low rate of adoption of this system is due to the limited infrastructure, financial resources, technological knowledge and personal skills, as well as social barriers (Macedo, 2009; Euclides et al., 2010).

\section{Conclusions}

Intercropping of corn silage with palisade grass is a viable option for the diversification of agricultural activities, enabling the use of land throughout the year. In Brazil, many farmers produce only one crop per year. However, the use of an integrated crop-livestock system enables corn production for silage in the summer/autumn with later pasture formation in the winter/spring for lamb finishing in a semifeedlot in the same field.

Analyzing the system as a whole, intercropping corn silage with palisade grass (cv. Marandu) followed by palisade grass (cv. Piatã) with a cutting height of $0.45 \mathrm{~m}$ combined with yellow oat oversowing was the most robust option for enhancing productivity. Silage production, subsequent pasture formation for lamb finishing in a semi-feedlot system, the reduction of silage and concentrate intake, and greater live weight and carcass gains per hectare were all key attributes for improving the economic viability of this integrated crop-livestock system.

\section{Acknowledgments}

The authors thank the São Paulo Research Foundation (FAPESP) (grant \# 2011/12155-3, \# 2010/12992-0, \# 2011/03662-9 and \# 2012/04458-9) and the Foundation for the Development of UNESP (FUNDUNESP) for their financial support (grant \# 0540/011/14$\mathrm{PROPe} / \mathrm{CDC}$ ). The authors also thank the Coordination of Improvement of Higher Education Personnel (CAPES) for the grant to the first author and the National Council for Scientific and Technological Development (CNPq) for an award for excellence in research to the second, third and sixth authors. The authors also thank Sementes JC Maschietto for providing the palisade grass seeds.

\section{References}

Agrolink, 2016. Quotations to Farming.Available at. www.agrolink.com.br (Acessed on July 06, 2016).

Alvares, C.A., Stape, J.L., Serntelhas, P.C., Gonçalves, J.L.M., Sparovek, G., 2013. Köppen's climate classification map for Brazil. Meteorol. Z. 22:711-728. http://dx.doi.org/10. 1127/0941-2948/2013/0507.

Anghinoni, I, 2007. Fertilidade do solo e seu manejo em sistema plantio direto. In: Novais, R.F., V. Alavares, V.H., Barros, N.F., Fontes, R.L.F., Cantarutti, R.B., Neves, J.C.L. (Eds.), Fertilidade do solo, first ed. SBCS, Viçosa, pp. 873-928 (In Portuguese)

Anualpec, 2016. Anuário da Pecuária Brasileira. Instituto FNP, São Paulo (272 pp). 
Arshad, M.A., Lowery, B., Grossman, B., 1996. Physical tests for monitoring soil quality. In: Doran, J.W., Jones, A. (Eds.), Methods for Assessing Soil Quality. Soil Science Society of America, Madison, pp. 123-141 (Special Publication, 49).

Balbinot Júnior, A.A., Moraes, A., Veiga, M., Pelissari, A., Dieckow, J., 2009. Crop-livestock system: intensified use of agricultural lands. Cienc. Rural 39:1925-1933. http://dx. doi.org/10.1590/S0103-84782009005000107 (In Portuguese, with English abstract.).

Barro, R.S., Saibro, J.C., Medeiros, R.B., Silva, J.L.S., Varella, A.C., 2008. Forage yield and nutritive value of cool-season annual forage grasses shaded by Pinus elliottii trees and at full-sun. Rev. Bras. Zootec. 10:1721-1727. http://dx.doi.org/10.1590/S151635982008001000002 (In Portuguese, with English abstract.).

Barros, C.S., Monteiro, A.L.G., Poli, C.H.E.C., Dittrich, J.R., Canziani, J.R.F., Fernandes, M.A.M., 2009. Economic return of sheep production on pasture and in feedlot. Rev. Bras. Zootecn. 38:2270-2279. http://dx.doi.org/10.1590/S1516-35982009001100029 (In Portuguese, with English abstract.).

Barth Neto, A., Savian, J.V., Schons, R.M.T., Bonnet, O.J.F., Canto, M.W., Moraes, A., Lemaire, G., Carvalho, P.C.F., 2014. Italian ryegrass establishment by self-seeding in integrated crop-livestock systems: Effects of grazing management and crop rotation strategies. Eur. J. Agron. 53:67-73. http://dx.doi.org/10.1016/j.eja.2013.11.001.

Borghi, E., Crusciol, C.A.C., Nascente, A.S., Mateus, G.P., Martins, P.O., Costa, C., 2012. Effects of row spacing and intercrop on maize grain yield and forage production of palisade grass. Crop Pasture Sci. 63:1106-1113. http://dx.doi.org/10.1071/CP12344.

Borghi, E., Crusciol, C.A.C., Nascente, A.S., Souza, V.V ., Martins, P.O., Mateus, G.P. Costa, C., 2013a. Sorghum grain yield, forage biomass production and revenue as affected by intercropping time. Eur. J. Agron. 51:130-139. http://dx.doi.org/10.1016/j.eja.2013. 08.006 .

Borghi, E., Crusciol, C.A.C., Mateus, G.P., Nascente, A.S., Martins, P.O., 2013b. Intercropping time of corn and palisadegrass or guineagrass affecting grain yield and forage production. Crop Sci. 53:629-636. http://dx.doi.org/10.2135/cropsci2012.08.0469.

Borghi, E., Crusciol, C.A.C., Trivelin, P.C.O., Nascente, A.S., Costa, C., Mateus, G.P., 2014. Nitrogen fertilization $\left(15 \mathrm{NH}_{4} \mathrm{NO}_{3}\right)$ of palisadegrass and residual effect on subsequent no-tillage corn. Rev. Bras. Ciênc. Solo 38:1457-1468. http://dx.doi.org/10.1590/ S0100-06832014000500011.

Brasil. Ministério da Agricultura, Pecuária e do Abastecimento (MAPA), 2000e. Secretaria da Defesa Agropecuária (SDA). Departamento de Inspeção de Produtos de Origem Animal (DIPOA). Divisão de Normas Técnicas. Instrução Normativa n. 3, de 17 de janeiro de 2000. Aprova o Regulamento Técnico de Métodos de Insensibilização para o Abate Humanitário de Animais de Açougue. Lex: Diário Oficial da União de 24 de janeiro de 2000, seção I, pp. 14-16. Brasília.Available at. http://www. defesaagropecuaria.sp.gov.br/www/legislacoes/popup.php?action = view\&idleg= 661 (accessed June 21, 2014). (In Portuguese).

Cantarella, H., van Raij, B., Camargo, C.E.O., 1997. Cereais. In: van Raij, B., Cantarella, H., Quaggio, J.A., Furlani, A.M.C. (Eds.), Boletim Técnico 100, Recomendação de Adubação e Calagem para o Estado de São Paulo, second ed. Instituto Agronômico, Campinas, pp. 43-71 (In Portuguese).

Carnevalli, R.A., Silva, S.C., Fagundes, J.L., Sbrissia, A.F., Carvalho, C.A.B., Pinto, L.F.M., Pedreira, C.G.S., 2001. Pasture and sheep performance on tifton 85 (Cynodon spp.) pastures under continuous stocking. Sci. Agric. 58:7-15. http://dx.doi.org/10.1590/ S0103-90162001000100002 (In Portuguese, with English abstract.).

Carvalho, P.C.F., Anghinoni, I., Moraes, A., Souza, E.D., Sulc, R.M., Lang, C.R., Flores, J.P.C., Lopes, M.L.T., Silva, J.L.S., Conte, O., Wesp, C.L., Levien, R., Fontaneli, R.S., Bayer, C., 2010. Managing grazing animals to achieve nutrient cycling and soil improvement in no-till integrated systems. Nutr. Cycl. Agroecosyst. 88:259-273. http://dx.doi.org/ 10.1007/s10705-010-9360-x.

Cornell Net Carbohydrate and Protein System, 2000. The Net Carbohydrate and Protein System for Evaluating Herd Nutrition and Nutrients Excretion, Version 5.0. CNCPS, Ithaca (237 pp).

Costa, K.A.P., Rosa, B., Oliveira, I.P., Custódio, D.P., Silva, D.C., 2005. Effect of seasonal climate condition on the dry matter production and bromatological composition of Brachiaria brizantha cv. Marandu. (In Portuguese, with English abstract.). Cienc. Anim. Bras. 6, 187-193.

Costa, N.R., Andreotti, M., Gameiro, R.A., Pariz, C.M., Buzetti, S., Lopes, K.S.M., 2012. Nitrogen fertilization in the intercropping of corn with two Brachiaria species in a no-tillage system. Pesqui. Agropecu. Bras. 47:1038-1047. http://dx.doi.org/10.1590/S0100204X2012000800003 (In Portuguese, with English abstract.)

Costa, N.R., Andreotti, M., Crusciol, C.A.C., Pariz, C.M., Lopes, K.S.M., Yokobatake, K.L.A., Ferreira, J.P., Lima, C.G.R., Souza, D.M., 2016. Effect of intercropped tropical perennial grasses on the production of sorghum-based silage. Agron. J. 108:2379-2390. http:// dx.doi.org/10.2134/agronj2016.07.0385.

Crusciol, C.A.C., Mateus, G.P., Pariz, C.M., Borghi, E., Costa, C., Silveira, J.P.F., 2011. Nutrition and sorghum hybrids yield with contrasting cycles intercropped with Marandu grass. Pesq. Agrop. Brasileira 46:1234-1240. http://dx.doi.org/10.1590/S0100204X2011001000017 (In Portuguese, with English abstract.)

Crusciol, C.A.C., Mateus, G.P., Nascente, A.S., Martins, P.O., Borghi, E., Pariz, C.M., 2012. An innovative crop-forage intercrop system: early cycle soybean cultivars and palisadegrass. Agron. J. 104:1085-1095. http://dx.doi.org/10.2134/agronj2012.0002.

Crusciol, C.A.C., Nascente, A.S., Mateus, G.P., Borghi, E., Leles, E.P., Santos, N.C.B., 2013. Effect of intercropping on yields of corn with different relative maturities and palisadegrass. Agron. J. 105:599-606. http://dx.doi.org/10.2134/agronj2012.0426.

Crusciol, C.A.C., Nascente, A.S., Mateus, G.P., Pariz, C.M., Martins, P.O., Borghi, E., 2014. Intercropping soybean and palisadegrass for enhanced land use efficiency and revenue in a no till system. Eur. J. Agron. 58:53-62. http://dx.doi.org/10.1016/j.eja.2014. 05.001.

Crusciol, C.A.C., Marques, R.R., Carmeis Filho, A.C.A., Soratto, R.P., Costa, C.H.M., Ferrari Neto, J., Castro, G.S.A., Pariz, C.M., Castilhos, A.M., 2016. Annual crop rotation of tropical pastures with no-till soil as affected by lime surface application. Eur. J. Agron. 80: 88-104. http://dx.doi.org/10.1016/j.eja.2016.07.002.
Euclides, V.P.B., Valle, C.B., Macedo, M.C.M., Almeida, R.G., Montagner, D.B., Barbosa, R.A. 2010. Brazilian scientific progress in pasture research during the first decade of XX century. Rev. Bras. Zootec. 39, suppl.spe, 151-168. doi: 10.1590/S151635982010001300018 .

FAO - Food and Agriculture Organization of the United Nations, 2006o. World reference base for soil resources 2006: a framework for international classification, correlation and communication. Rome, WorldSoil Resources Reports No. 103 Available at: http://www.fao.org/nr/land/sols/soil/en/ (accessed June 06, 2013).

FAO - Food and Agriculture Organization of the United Nations, 2016o. Integrated CropLivestock Systems (ICLS).Available at:. http://www.fao.org/agriculture/crops/corethemes/theme/spi/scpi-home/managing-ecosystems/integrated-crop-livestocksystems/en/ (accessed January 28, 2016).

Franzluebbers, A.J., Stuedemann, J.A., 2014. Crop and cattle production responses to tillage and cover crop management in an integrated crop-livestock system in the southeastern USA. Eur. J. Agron. 57:62-70. http://dx.doi.org/10.1016/j.eja.2013.05.009.

Gerdes, L., Mattos, H.B., Werner, J.C., Colozza, M.T., Santos, L.E., Cunha, E.A., Bueno, M.S. Schammass, E.A., 2005. Forage canopy characteristics and forage accumulation in irrigated aruanagrass pastures or oversown with a mixture of winter forage species. Rev. Bras. Zootec. 34:1080-1097. http://dx.doi.org/10.1590/S151635982005000400002 (In Portuguese, with English abstract.).

Heinrichs, J., 1996. Evaluating particle size of forages and TMRs using the Penn State particle size separator. Tech. Bull. No. DAS 96-20. Coll. Agric. Sci. Pennsylvania State Univ., University Park

Herrero, M., Thornton, P.K., Notenbaert, A.M., Wood, S., Msangi, S., Freeman, H.A., Bossio D., Dixon, J., Peters, M., van Steeg, J., Lynam, J., Rao, P.P., Macmillan, S., Gerard, B., McDermott, J., Seré, C., Rosegrant, M., 2010. Smart investments in sustainable food production: revisiting mixed crop-livestock systems. Science 327:822-825. http:// dx.doi.org/10.1126/science.1183725.

IBGE - Instituto Brasileiro de Geografia e Estatísticas, 2010. Produção da Pecuária municipal. 38. IBGE, Rio de Janeiro 65 pp. Available at:. http://www.ibge.gov.br/home/ estatistica/economia/ppm/2010/ (accessed August 12, 2013).

Kiehl, E.J., 1979. Manual de edafologia: relações solo-planta. Agronômica Ceres, Piracicaba, p. 264 (In Portuguese).

Lopes, M.L.T., Carvalho, P.C.F., Anghinoni, I., Santos, D.T., Kuss, F., Freitas, F.K., Flores, J.P.C. 2008. Crop-livestock integration system: performance and carcass quality of superprecoce beef steers finished in oat and ryegrass pasture managed under different heights. Cienc. Rural 38:178-184. http://dx.doi.org/10.1590/S010384782008000100029.

Macedo, M.C.M., 2009. Crop and livestock integration: the state of the art and the near future. Rev. Bras. Zootec. 38 (special issue):133-146. http://dx.doi.org/10.1590/S151635982009001300015 (In Portuguese, with English abstract.).

Macedo, F.A.F., Siqueira, E.R., Martins, E.N., 2000. Economical analysis of meat lamb production under two finishing systems: pasture and dry-lot. Cienc. Rural. 30:677-680. http://dx.doi.org/10.1590/S0103-84782000000400020 (In Portuguese, with English abstract.).

Mateus, G.P., Borghi, E., Marques, R.R., Bôas, R.L.V., Crusciol, C.A.C., 2007. Sources and time of contact of mineral fertilizer with Brachiaria brizantha seeds as related with germination. Rev. Bras. Ciênc. Solo 31:177-183. http://dx.doi.org/10.1590/S0100 06832007000100018 (In Portuguese, with English abstract.).

Mateus, G.P., Crusciol, C.A.C., Borghi, E., Pariz, C.M., Costa, C., Silveira, J.P.F., 2011. Nitrogen fertilization on sorghum intercropped with grass in a no-tillage system. Pesqui. Agropecu. Bras. 46:1161-1169. http://dx.doi.org/10.1590/S0100-204X2011001000007 (In Portuguese, with English abstract.).

Mateus, G.P., Crusciol, C.A.C., Borghi, E., 2012. Integrated crop-livestock: the new green revolution in the tropics. (In Portuguese). Pesqui. Tecnol. 4, 1-5.

Mateus, G.P., Crusciol, C.A.C., Pariz, C.M., Borghi, E., Costa, C., Martello, J.M., Franzluebbers, A.J., Castilhos, A.M., 2016. Sidedress nitrogen application rates to sorghum intercropped with tropical perennial grasses. Agron. J. 108:433-447. http://dx.doi. org/10.2134/agronj2015.0236.

Matsunaga, M., Bemelmans, P.F., Toledo, P.E.N., Dulley, R.D., Okawa, H., Pedroso, I.A., 1976 Metodologia de custo de produção utilizada pelo IEA. Agricultura em São Paulo. 23, 123-139 (In Portuguese)

Medeiros, G.R., Costa, A.R.G., Andrade, M.G.L.P., Azevedo, P.S., Pinto, A.N., Soares, J.N., Susssuna, J.M.A., 2011. Fat depots in carcass of Santa Inês and Morada Nova sheep slaughtered at different weights. Actas Iberoamericanas de Conservación Animal 1, 243-246.

Mertens, D.R., 1997. Creating a system for meeting the fiber requirements of dairy cows. J. Dairy Sci. 80, 1463-1481.

Molento, M.B., 2009. Método Famacha no controle de Haemonchus contortus. In: Cavalcante, A.C.R., Vieira, L.S., Chagas, A.C.S., Molento, M.B. (Eds.), Doenças parasitárias de caprinos e ovinos: epidemiologia e controle. Embrapa, Brasília pp. 367-400 (In Portuguese).

Moraes, A., Carvalho, P.C.F., Anghinoni, I., Lustosa, S.B.C., Costa, S.E.V.G.A., Kunrath, T.R. 2014a. Integrated crop-livestock systems in the Brazilian subtropics. Eur. J. Agron. 57:4-9. http://dx.doi.org/10.1016/j.eja.2013.10.004

Moraes, A., Carvalho, P.C.F., Lustosa, S.B.C., Lang, C.R., Deiss, L., 2014b. Research on integrated crop-livestock systems in Brazil. Rev. Ciênc. Agron. 45:1024-1031. http://dx doi.org/10.1590/S1806-66902014000500018.

Moreno, G.M.B., Sobrinho, A.G.S., Leão, A.G., Loureiro, C.M.B., Perez, H.L., 2010. Carcass yield, tissue composition, and leg muscularity of lambs fed corn silage or sugar cane in two levels of concentrate. Arq. Bras. Med. Vet. Zootec. 62:686-695. http:// dx.doi.org/10.1590/S0102-09352010000300025 (In Portuguese, with English abstract.).

Mott, G.O., 1980. Measuring forage quantity and quality in grazing trials. Southern Pasture and Forage Crop Improvement Conference, 37, NashvilleProceddings... Nashville: AESA/ARS, pp. 3-9. 
NRC - National Research Council, 2007. Nutrient Requirements of Small Ruminants. National Academy Press, Washington (362 pp).

Osório, J.C.S., Osório, M.T.M., Oliveira, N.M., Siewerdt, N.M., 2002. Qualidade, morfologia e avaliação de carcaças. Universitária, Pelotas 197 pp. (In Portuguese).

Parente, H.N., Machado, T.M.M., Carvalho, F.C., Garcia, R., Rogério, M.C.P., Barros, N.N.N Zanine, A.M., 2009. Performance of confined sheep fed different diets. Arq. Bras. Med. Vet. Zootec. 61:460-466. http://dx.doi.org/10.1590/S0102-09352009000200025 (In Portuguese, with English abstract.).

Pariz, C.M., Andreotti, M., Tarsitano, M.A.A., Bergamaschine, A.F., Buzetti, S., Chioderolli, C.A., 2009. Technical and economic performance of corn intercropped with Panicum and Brachiaria forage in crop-livestock integration system. (In Portuguese, with English abstract.). Pesqu. Agropecu. Trop. 39, 360-370.

Pariz, C.M., Andreotti, M., Azenha, M.V., Bergamaschine, A.F., Mello, L.M.M., Lima, R.C., 2010. Dry mass and chemical composition of four Brachiaria species sown in rows or spread, in intercrop with corn crop in no-tillage system. Acta Sci-Anim. Sci. 32: 147-154. http://dx.doi.org/10.4025/actascianimsci.v32i2.8498 (In Portuguese, with English abstract.).

Pariz, C.M., Andreotti, M., Bergamaschine, A.F., Buzetti, S., Costa, N.R., Cavallini, M.C. 2011a. Production, chemical composition and chlorophyll index of Brachiaria spp. after the intercrop with corn. Arch. Zootec. 60:1041-1052. http://dx.doi.org/10. 4321/S0004-05922011000400020 (In Portuguese, with English abstract.).

Pariz, C.M., Andreotti, M., Bergamaschine, A.F., Buzetti, S., Costa, N.R., Cavallini, M.C., Ulian, N.A., Luiggi, F.G., 2011b. Yield, chemical composition and chlorophyll relative content of Tanzania and Mombaça grasses irrigated and fertilized with nitrogen after corn intercropping. Rev. Bras. Zootec. 40:728-738. http://dx.doi.org/10.1590/S151635982011000400005

Pariz, C.M., Andreotti, M., Azenha, M.V., Bergamaschine, A.F., Mello, L.M.M., Lima, R.C., 2011c. Corn grain yield and dry mass of Brachiaria intercrops in the crop-livestock integration system. Cienc. Rural 41:875-882. http://dx.doi.org/10.1590/S010384782011000500023 (In Portuguese, with English abstract.).

Pariz, C.M., Carvalho, M.P., Chioderoli, C.A., Nakayama, F.T., Andreotti, M., Montanari, R. 2011d. Spatial variability of forage yield and soil physical attributes of a Brachiaria decumbens pasture in the Brazilian Cerrado. Rev. Bras. Zootec. 40:2111-2120. http://dx.doi.org/10.1590/S1516-35982011001000007.

Pariz, C.M., Costa, C., Crusciol, C.A.C., Meirelles, P.R.L., Castilhos, A.M., Andreotti, M., Costa, N.R., Martello, J.M., Souza, D.M., Sarto, J.R.W., Franzluebbers, A.J., 2016. Production and soil responses to intercropping of forage grasses with corn and soybean silage. Agron. J. 108:2541-2553. http://dx.doi.org/10.2134/agronj2016.02.0082.

Piazzetta, H.V.L., Monteiro, A.L.G., Ribeiro, T.M.D., Carvalho, P.C.F., Dittrich, J.R., Silva, C.J.A 2009. Intake behavior of lambs finished on pasture. Acta Sci-Anim. Sci. 31:227-234. http://dx.doi.org/10.4025/actascianimsci.v31i3.5345 (In Portuguese, with English abstract.).

Poli, C.H.E.C., Monteiro, A.L.G., Barros, C.S.B., Moraes, A., Fernandes, M.A.M., Piazetta, H.V.L., 2008. Meat sheep production on four different production systems. Rev. Bras. Zootec. 37:666-673. http://dx.doi.org/10.1590/S1516-35982008000400012 (In Portuguese, with English abstract.).
Ribeiro, T.M.D., Monteiro, A.LG, Poli, C.H.E.C Moraes, A Silva, A.LP Barros, C.S., 2009. Ryegrass pasture characteristics and lamb productivity in grazing. Rev. Bras. Zootec. 38:580-587. http://dx.doi.org/10.1590/S1516-35982009000300025 (In Portuguese, with English abstract.).

Rosa, G.T., Pires, C.C., Silva, J.H.S., Motta, O.S., 2002. Proportions and Coefficients of Growth Components, Non-Carcass of the Live Weight of Male and Female Lambs under Different Feeding Methods. 31:pp. 2290-2298. http://dx.doi.org/10.1590/S151635982002000900018 (In Portuguese, with English abstract.).

Santos, G.J., Marion, J.C., Segatti, S., 2008. Administração de custos na agropecuária. third ed. Atlas, São Paulo 165 pp. (In Portuguese).

SAS Institute, 2015. Procedure Guide for Personal Computers. Version 9.4. Cary

Savian, J.V., Barth Neto, A., David, D.B., Bremm, C., Schons, R.M.T., Genro, T.C.M., Amaral, G.A., Gere, J., McManus, C.M., Bayer, C., Carvalho, P.C.F., 2014. Grazing intensity and stocking methods on animal production and methane emission by grazing sheep: Implications for integrated crop-livestock system. Agric. Ecosyst. Environ. 190:112-119. http://dx.doi.org/10.1016/j.agee.2014.02.008.

Shapiro, S.S., Wilk, M.B., 1965. An analysis of variance test for normality (complete samples). Biometrika 52, 591-611.

Silva, D.J., Queiroz, A.C., 2002. Análise de Alimentos: Métodos Químicos e Biológicos. third ed. UFV, Viçosa 235 pp. (In Portuguese).

Silva Sobrinho, A.G., 2001. Aspectos quantitativos e qualitativos da produção de carne ovina. A Produção Animal na Visão dos Brasileiros. FEALQ, Piracicaba, pp. 425-446 (In Portuguese).

Stolf, R., Murakami, J.H., Brugnaro, C., Silva, L.G., Silva, L.C.F., Margarido, L.A.C., 2014. Stolf impact penetrometer - computer data program in EXCEL-VBA. Rev. Bras. Ciênc. Solo 38:774-782. http://dx.doi.org/10.1590/S0100-06832014000300009 (In Portuguese, with English abstract.).

Tracy, B.F., Zhang, Y., 2008. Soil compaction, corn yield response, and soil nutrient pool dynamics within an integrated crop-livestock system in Illinois. Crop Sci. 48: 1211-1218. http://dx.doi.org/10.2135/cropsci2007.07.0390.

Unicamp - Universidade Estadual de Campinas, 2012. Centro de Pesquisas Meteorológicas e Climáticas Aplicadas a Agricultura. Clima dos Municípios Paulistas, Botucatu Available at:. http://www.cpa.unicamp.br/outras-informacoes/clima_muni_086.html\# (accessed February 18, 2014). (In Portuguese).

van Raij, B., Andrade, J.C., Cantarella, H., Quaggio, J.A., 2001. Análise química para avaliação da fertilidade de solos tropicais. IAC, Campinas 284 pp. (In Portuguese).

Weiss, W.P., Wyatt, D.J., 2000. Effect of oil content and kernel processing of corn silage on digestibility and milk production by dairy cows. J. Dairy Sci. 83:351-358. http://dx. doi.org/10.3168/jds.S0022-0302(00)74886-7.

Wirsenius, S., Azar, C., Berndes, G., 2010. How much land is needed for global food production under scenarios of dietary chances and livestock productivity increases in 2030? Agric. Syst. 103:621-638. http://dx.doi.org/10.1016/j.agsy.2010.07.005.

Yokoyama, L.P. Viana Filho, A., Balbino, L.C. Oliveira, I.P., Barcellos, A.O. 1999. Economic evaluation of different technologies for pasture recuperation. Pesq. Agrop. Brasileira 34:1335-1345. http://dx.doi.org/10.1590/S0100-204X1999000800003 (In Portuguese, with English abstract.). 